Florida International University FIU Digital Commons

FIU Electronic Theses and Dissertations

University Graduate School

6-6-2011

\title{
Essays on Administrative Protection and Trade Deflection
}

Veysel Avsar

Florida International University, vavsa001@fiu.edu

DOI: $10.25148 /$ etd.FI1 1072608

Follow this and additional works at: https:// digitalcommons.fiu.edu/etd

Part of the Economics Commons

\section{Recommended Citation}

Avsar, Veysel, "Essays on Administrative Protection and Trade Deflection" (2011). FIU Electronic Theses and Dissertations. 440. https://digitalcommons.fiu.edu/etd/440

This work is brought to you for free and open access by the University Graduate School at FIU Digital Commons. It has been accepted for inclusion in FIU Electronic Theses and Dissertations by an authorized administrator of FIU Digital Commons. For more information, please contact dcc@fiu.edu. 


\section{FLORIDA INTERNATIONAL UNIVERSITY}

Miami, Florida

\section{ESSAYS ON ADMINISTRATIVE PROTECTION AND TRADE DEFLECTION}

A dissertation submitted in partial fulfillment of the requirements for the degree of DOCTOR OF PHILOSOPHY

in

ECONOMICS

by

Veysel Avsar

2011 
To: Dean Kenneth Furton

College of Arts and Sciences

This dissertation, written by Veysel Avsar, and entitled Essays on Administrative Protection and Trade Deflection, having been approved in respect to style and intellectual content, is referred to you for judgment.

We have read this dissertation and recommend that it be approved.

$\begin{array}{r}\text { Jesse Bull } \\ \hline \text { Sheng Guo } \\ \hline \text { Cem Karayalcin } \\ \hline \text { Hehmet Ulubasoglu } \\ \hline \text { Richard Chisik, Major Professor }\end{array}$

Date of Defense: June 6, 2011

The dissertation of Veysel Avsar is approved.

Dean Kenneth Furton College of Arts and Sciences

Interim Dean Kevin O'Shea University Graduate School

Florida International University, 2011 


\section{DEDICATION}

I dedicate this dissertation to my wife, my parents, my sister and my son who will be born shortly. 


\section{ACKNOWLEDGMENTS}

This dissertation benefitted from many individuals' contributions along the way. I would like to express my deep appreciation and gratitude to those who inspired and helped me through this long process. My major Professor, Richard Chisik, has been the prime scholar to give me the inspiration to write a dissertation on international trade. He has spent a lot of time discussing research with me and going over the ideas. I am proud to call him my advisor.

Professors on my committee, Cem Karayalcin, Jesse Bull, Sheng Guo, Mehmet Ulubasoglu and Hassan Zahedi provided me their invaluable feedback and contributed greatly to my study. I would like thank all for their time, patience and support. I also want to thank Peter Thompson for his crucial comments in the department seminars.

I also owe a big debt of gratitude to Marc Muendler for kindly inviting me to University of California San Diego (UCSD) to work with SECEX and RAIS data, sharing his data preparation codes, providing computational support and answering all of my related questions. I want to thank UCSD Department of Economics, where part of this research was undertaken, for hospitality

Finally, I would like to give utmost appreciation to Florida International University's Doctoral Evidence Acquisition Fellowship and Dissertation Year Fellowship. 


\section{ABSTRACT OF THE DISSERTATION \\ ESSAYS ON ADMINISTRATIVE PROTECTION AND TRADE \\ DEFLECTION \\ by \\ Veysel Avsar \\ Florida International University, 2011 \\ Miami, Florida \\ Professor Richard Chisik, Major Professor}

This dissertation analyzes the trading effects and the politics of antidumping. The first essay empirically examines the influence of partisanship on antidumping. I show that an increase in the leftist orientation of the government makes labor intensive industries less likely to file an antidumping petition. I also demonstrate that the increase in the leftist orientation of the government is associated with an increase in the likelihood of an affirmative antidumping outcome for the petitions of labor intensive industries.

The second essay investigates the effect of past exporting relationships of the firms, whose products are targeted by antidumping duties, on their export flows to alternative markets. My estimations show that facing an antidumping duty on a product leads to a $18 \%$ increase in the exports of the firm for that product to the alternative countries where the firms previously exported the same product and a $8 \%$ increase to the 
countries where the firms exported another product. On the contrary, I fail to find a significant effect of antidumping duties on the exports of the particular product to third countries to which the firm did not export before. Further, I show that a firm's probability to start exporting the duty imposed product in a different destination increases by $8-10 \%$ if the firm already exported another product to that destination. However, I find no such evidence for the countries to which the firm did not export before.

The third essay empirically analyzes the effect of potential antidumping claims, resulting from an antidumping investigation in the domestic market, on the quality of exported products to the target countries. My findings suggest that retaliation threats increase the quality of firms' shipments for the named industries' products to the target countries by $11 \%$. This effect is also significantly increasing in the share of the exports of the named industries' products shipped to the target country in the firms' total exports. Further, I show that this effect is $4 \%$ higher for the exporters serving the developed countries and $3 \%$ higher for ones serving the heavy antidumping users. 


\section{TABLE OF CONTENTS}

CHAPTER

PAGE

CHAPTER I: INDUSTRY LEVEL EVIDENCE ON PARTISAN TRADE POLICY: TARIFF vs. ANTIDUMPING 1

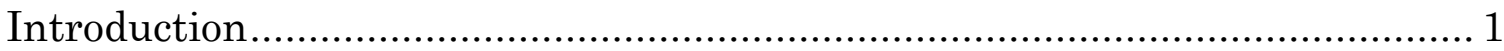

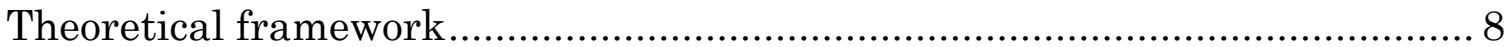

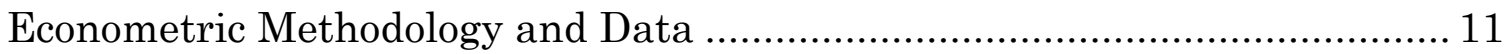

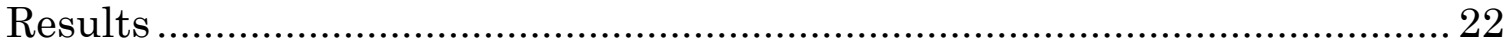

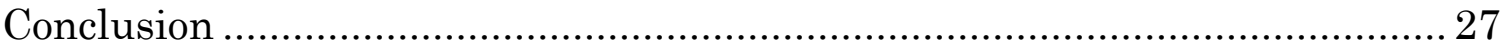

CHAPTER II: THE ANATOMY OF TRADE DEFLECTION

35

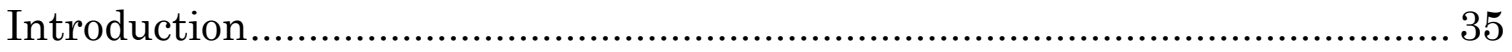

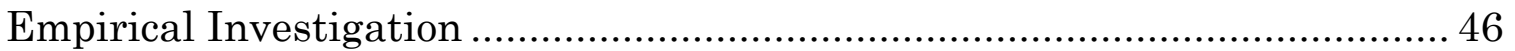

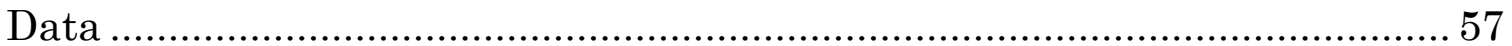

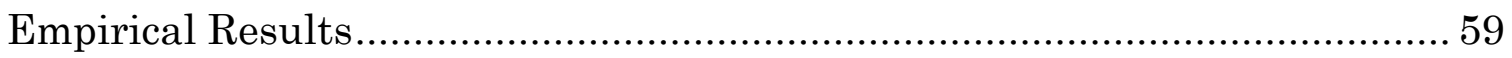

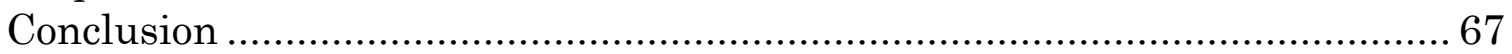

CHAPTER III: RETALIATION THREATS AND THE QUALITY OF EXPORTS

81

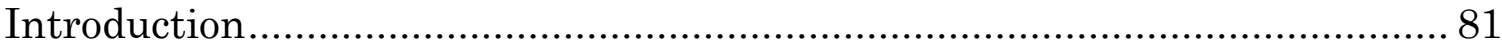

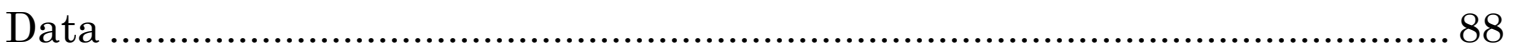

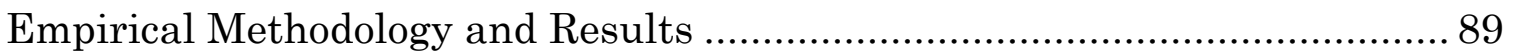

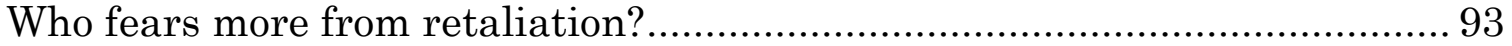

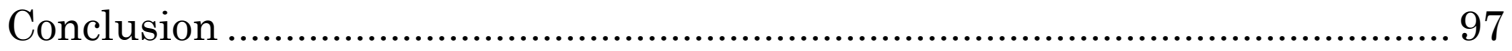

$\begin{array}{ll}\text { LIST OF REFERENCES } & 104\end{array}$

$\begin{array}{ll}\text { VITA } & 110\end{array}$ 


\section{LIST OF TABLES}

TABLE

PAGE

1.1. Summary Statistics ( Industry level) 29

1.2. Summary Statistics (Case level) 30

1.3. Regression Estimates of Three digit ISIC tariff 31

1.4. Linear Probability Model Estimates of Antidumping filings 32

1.5. Linear Probability Model Estimates of Antidumping 33

1.6. Heckman Selection Model of Antidumping Initiations and Outcomes 34

2.1. Antidumping duties imposed on Brazil 71

2.2. Summary Statistics $\quad 74$

2.3. IV First Difference Estimation $\quad 75$

2.4. Fixed Effects Estimation $\quad 76$

2.5. IV First Difference Estimation (Steel vs. Non-steel products) 77

2.6. IV First Difference Estimation of Extensive Margin 78

2.7. Fixed Effects Estimation of Extensive Margin 79

2.8. IV First Difference Estimation of Extensive Margin 80

3.1. Brazil's Antidumping Filings by Industries 99

3.2. Defendant Countries in Brazil's Antidumping Investigations 100

3.3. Summary Statistics 101

3.4. Estimation Results 102

3.5. Who fears more from retaliation? 103 


\section{LIST OF ABBREVIATIONS}

\begin{tabular}{ll} 
AD & Antidumping \\
BC & Bown and Crowley \\
DM & Dutt and Mitra \\
EU & European Union \\
FE & Fixed Effect \\
GATT & General Agreements on Tariffs and Trade \\
HS & Harmonized System \\
ISIC & International Standard Industrial Classification \\
IV & Instrumental Variable \\
KV & Konings and Vandenbussche \\
MJ & Milner and Judkins \\
NAFTA & North American Free TradeAgreement \\
NCM & Nomenclatura Comum do Mercosul \\
OLS & Ordinary Least Squares \\
RAIS & Relacao Anual de Informacoes Sociais \\
SECEX & Secretaria de Comércio Exterior \\
US & United States \\
WTO & World Trade Organization \\
\hline
\end{tabular}




\section{CHAPTER 1}

\section{INDUSTRY LEVEL EVIDENCE ON PARTISAN TRADE POLICY: TARIFF vs. ANTIDUMPING}

\section{Introduction}

To date, the role of political ideology in the choice of economic policy instruments has received serious attention by political economists. Much of the existing studies suggest that in a democratic regime, political parties which compete for electoral votes try to adopt policies in favor of their electoral base. Hence, it is the constituents' interests which determine the ideological attitude of the governments. Generally, the political party that is in the left ideological spectrum represents workers, whereas the right-wing represents capital owners. ${ }^{1}$

Trade policy is one of the policy instruments, which enables a political party to differentiate itself from others to compete for votes. The redistributive consequence of the trade policy is the pivotal argument of the political economists who have emphasized the partisan-based trade policy. For instance, Milner and Judkins (2004), henceforth MJ, investigate the relationship between "class cleavage based partisanship" and "trade policy" of a political party and find that left-wing parties in advanced industrial countries adopt more protectionist policies compared to

\footnotetext{
${ }^{1}$ See Hibbs (1977), Alesina(1987), Hibbs, Rivers and Vasilatos (1982), Pinto and Pinto (2008)
} 
the right-wing parties. Focusing on US trade policy between 1877 and 1934, Epstein and O.Halloran (1996) showed that Republicans raised the tariffs, while Democrats cut them. Rogowski (1989, pp. 98) predicts that in countries, such as United States, Canada, Australia and New Zealand, which are capital and land rich, left-wing parties should be protectionist. By combining the political support function of Hillman (1989) with StoperSamuelson theorem, Dutt and Mitra (2005), henceforth (DM), show that leftwing governments are protectionist in capital abundant countries, whereas they are pro-trade in labor abundant countries when compared to their rightwing counterparts. Further, Krever (2008) highlights the impact of partisan preferences on the government's decision to form preferential trade agreements. His results indicate that independent of its factor endowments, a country is more likely to form preferential trade agreements when there is a right-wing government in power.

In this paper, I exploit the three-digit ISIC industries' trade and protection data to analyze the effect of political ideology on trade policy. My first focus is the level of tariffs, which is an extension of DM (2005) to the industry level. Second, I examine whether the political ideology of the governments affect the usage of antidumping. In this regard, my study represents the first attempt to integrate antidumping in the study of partisan trade policy. 
Antidumping has become the most effective contingent protection tool in the past 20 years. Until the late 1980 s, the use of $\mathrm{AD}$ was limited to developed countries; however, its world-wide use has increased over the past decade. According to Bown (2008), more than 40 members of the World Trade Organization (WTO) have become active users of AD. The WTO records also show that there were 4,364 $\mathrm{AD}$ cases initiated between 1991 and 2007. Aggarwal (2007, pp.151, 152) notes three possible perspectives for the rationale behind the proliferation of $\mathrm{AD}$ : the political perspective, the political economy perspective, and the economic perspective. The first two argues that $\mathrm{AD}$ is a GATT/WTO legal trade remedy used to provide protection to the domestic firms which is injured by the imports of their foreign competitors. On the other hand, $\mathrm{AD}$ is a policy which aims to prevent predatory dumping, a situation where unfair pricing drives the domestic firms out of the market, according to the economic perspective. In this study, I build on the "political economy perspective" to antidumping and seek evidence as to whether the political ideology of the government has an effect on $\mathrm{AD}$ usage.

Antidumping has some appealing features that have led to fruitful approaches for researchers. The main difference between $\mathrm{AD}$ and tariffs is that in order to receive protection in the form of an $\mathrm{AD}$ duty, a firm has to file an investigation and show evidence that the exporting firm's price is lower 
than the "fair price" it normally charges in its home market. In addition to this, it has to prove that the domestic industry is "materially injured" by the different pricing in different markets (WTO 1995, Article 2.1 and 3.4). In addition, Prusa (2001) argues that AD duties have larger effects on trade flows of particular goods, compared to MFN (Most favored nation) tariffs, given the fact that $\mathrm{AD}$ duties are 10 to 20 times higher than the MFN level. His results show that $\mathrm{AD}$ duties decrease the value of total imports by 30 $50 \%$. He also finds that even if the $\mathrm{AD}$ investigations do not result affirmatively, the initiations themselves decrease the imports for the goods subject to filings. Even though this last finding of Prusa (2001) is an incentive for firms to file an investigation, the fixed cost of each petition has an opposite effect on this incentive. On the other hand, Blonigen (2006) suggests that prior experience of firms in pursuing an $\mathrm{AD}$ petition increases the probability of a successful outcome.

Studies which examine the determinants of $\mathrm{AD}$ initiations also focus on the effect of changing macroeconomic conditions on $\mathrm{AD}$ filings. For instance, Feinberg (2005) analyzes the AD petitions of U.S. firms and shows that decrease in GDP growth rates and appreciation of domestic currency is associated with higher probability of $\mathrm{AD}$ initiations. Knetter and Prusa (2003) also arrived at the same conclusion. In addition, Francois and Neils 
(2006) finds that Mexican firms are more likely to file an $\mathrm{AD}$ petition in periods of current account deficit.

Another focus in the $\mathrm{AD}$ literature is the strategic consideration of the AD activity. Prusa and Skeath (2002) provide evidence that countries are more likely to name the exporters of the countries which previously filed $\mathrm{AD}$ cases against them. Using a nested logit framework where the first stage determines the decision to file an $\mathrm{AD}$ investigation and the second stage determines the government's decision to impose an $\mathrm{AD}$ duty, Blonigen and Bown (2003) show that potential retaliation threats affect both the initiations and outcomes of antidumping in the US. Further support comes from Feinberg and Reynolds (2006), who find strong evidence that retaliation is a significant factor in explaining the proliferation of worldwide $\mathrm{AD}$ filings.

Another strand of the literature seeks to explore the role of tariff liberalization in the use of $\mathrm{AD}$. The main point of these studies is the potential substitution between tariff and $\mathrm{AD}$, which is a result of the shift towards international competition via trade liberalization and the domestic pressures associated with this shift. Aggarwal (2007, pp. 179) shows that a decline in mean tariff rates leads to an increase in the total number of $\mathrm{AD}$ initiations in a country. In addition, Feinberg and Reynolds (2007) found that tariff cuts agreed in the Uruguay Round increased the likelihood of observing an $\mathrm{AD}$ petition. Using applied tariffs, as opposed to the bound tariffs used in 
Feinberg and Reynolds (2007), Moore and Zanardi (2008) support the substitution hypothesis of tariff and $\mathrm{AD}$ for the heavy users of $\mathrm{AD}$. Moreover, modifying the protection for sale model of Grossman and Helpman (1994), Bown and Tovar (2008) find that reduction in tariffs, stemming from India's trade policy reforms in 1990s, is associated with an increase in its $\mathrm{AD}$ activity, the heaviest $\mathrm{AD}$-user country in recent years.

In this paper, I examine the role of political ideology and $\mathrm{AD}$ activity by following the substitution argument of tariff and AD. My theory of protection is motivated by the earlier work of DM (2005). Simply put, StolperSamuelson theorem predicts that trade will increase the demand for the abundant factor in production and decrease for the scarce one. Therefore, in a capital intensive industry, it is the owners of labor who suffer, while capital owners gain from a shift towards protection. On the contrary, increased trade will benefit capital and hurt labor in labor intensive industries. DM (2005) argues that since importable good is the labor intensive one in a capital-rich country, an increase in the leftist orientation of the government increases the trade barriers in capital abundant countries, and an opposite scenario holds for the labor abundant countries. This hypothesis is strongly supported in DM (2005) with different types of protection tools such as tariffs, import duties and quotas. 
The main contribution of my study is the integration of $\mathrm{AD}$ use to examine the relationship between political ideology and protection. Besides, we also extend DM's work with an industry level estimation of tariffs using the recently available data of the protection of industries. In line with DM (2005), our results indicate that predictions of the partisan trade theory hold at the industry level as well. In addition, we empirically investigate how the government's political ideology affects the decision to file an AD petition. This also allows us to test the substitution of tariff and $\mathrm{AD}$ initiations for the domestic industries. Moreover, on the basis of the redistributive effect of trade policy, we also check whether the imposition of $\mathrm{AD}$ duties shows the same pattern as tariffs in terms of partisan preferences of the governments.. Furthermore, we conduct a robustness check for the measure of the ideology variable, as suggested by DM (2005). Finally, I also test the validity of our results addressing the sample selection bias in the set of $\mathrm{AD}$ initiations. In sum, my results suggest that political ideology of the governments affect the level of tariffs, $\mathrm{AD}$ filings of the industries as well as the $\mathrm{AD}$ duty imposition decision of the governments.

The rest of this paper is organized as follows. In section 2, I set up a theoretical model which provides testable implications for the effect of an increase in the leftist bias of the government on the tariff and $\mathrm{AD}$ use of industries. Section 3 describes the econometric approach and various 
specifications undertaken in our analysis. In Section 4, we briefly discuss the construction of data used in our empirical analysis. Section 5 presents the estimation results, and section 6 provides the concluding remarks.

\section{Theoretical Framework}

In this section we modify the model of DM (2002) to extend it to industry level, in order to show the effect of the government's ideology on protection. To do so let us consider an economy with $\mathrm{N}$ industries, each of which has two kinds of factor owners: workers and capitalists. ${ }^{2}$ Each good produced has a specific tariff of $t$ which generates a tariff revenue of $T(t)=$ $\operatorname{tm}(p)$ where $m(p)$ denotes the total imports. We assume that the share of industry $h$ in total tariff revenue is proportional to its production share in the economy and each factor owner receives tariff revenue proportional to their factor income share in an industry. Turning to the demand side, we suppose that individual preferences are identical and homothetic. An individual $i$ 's indirect utility function can, as a result, be written as $\Omega^{i}=I^{i}(t) V(t)$ where $I^{i}$ is her income. Total incomes of all capitalists and of all workers in industry $h$ are given respectively by

$$
\begin{gathered}
I_{h}^{K}(t)=r(t) K_{h}+\gamma \delta T(t) \\
I_{h}^{L}(t)=w(t) L_{h}+\gamma(1-\delta) T(t)
\end{gathered}
$$

\footnotetext{
${ }^{2}$ We assume that workers only own labor and capitalists only own capital.
} 
where $\gamma$ denotes the production share of industry $h$ and $\delta$ denotes the income share of capitalists in industry $h . w(t)$ and $r(t)$ denote the wage rate and the rental rate respectively.

Giving labor welfare the weight of a and capitalist welfare the weight of 1- $a$, the government chooses the level of tariff for industry $h$ to maximize its objective function which is given by

$$
\Omega^{G}(t)=\alpha \sum_{i \in L} \Omega_{h}^{i}+(1-\alpha) \sum_{i \in K} \Omega_{h}^{i}
$$

The above objective function can also be written as

$$
\Omega^{G}(t)=V(t) I^{A}(t)
$$

where $I^{A}$ is the weighted aggregate income given by

$$
I^{A}=(1+\tau) L_{h}\left[\left(\alpha \cdot r(t) k_{h}+(1-\alpha) w(t)\right]\right.
$$

where $k_{h}$ is the capital labor ratio of sector $i$ and $\tau$ is the ratio of total tariff revenue to total income of the economy.

Letting $I_{u}(\mathrm{t})$ denote the weighted income for an industry of unit size, the government maximizes $L_{h} \cdot V(t) I_{u}(t)$ which is also same as maximizing $\Phi=u(t)+\psi(\mathrm{t}) \quad$ where $\quad u(t)=\ln V(t)$ and $\psi(\mathrm{t})=\ln I_{u}(t)=\ln [\alpha w(t)+$ $\left.(1-\alpha) r(t) k_{h}\right]+\ln (1+\tau)$. We assume that this objective function satisfies the second order condition for a unique solution. The first order condition for government's maximization problem is 


$$
u^{\prime}(t)+\frac{\partial \psi}{\partial t}=0
$$

Let $t^{*}$ be the equilibrium protection here which maximizes the government's objective function. The key question is that how this protection level changes with the ideology of the government. The answer comes from differentiating the first order condition with respect to a, the weight government attaches on labor welfare. An increase in a can be interpreted as an increase in the leftist orientation of the government. By differentiating the first order condition we obtain

$$
\frac{\partial t^{*}}{\partial \alpha}=\frac{\left[r^{\prime}(t) w(t)-r(t) w^{\prime}(t)\right] k_{h}}{\left[\alpha w(t)+(1-\alpha) r(t) k_{h}\right]^{2}\left[v^{\prime \prime}(t)+\partial^{2} \psi / \partial t^{2}\right]}
$$

Given the fact that protection is beneficial for the owners of the factor which is used intensively in the production of the importable, we have $r^{\prime}(t)>0$ and $w^{\prime}(t)<0$ for a capital intensive industry, whereas $r^{\prime}(t)<0$ and $w^{\prime}(t)>0$ for a labor intensive industry. Due to the concavity assumption imposed, the denominator of the above derivative is always negative. Consequently, we have $\partial t^{*} / \partial a>0$ for labor intensive industries, while $\partial t^{*} / \partial a<0$ for capital intensive industries.

Since tariff is the major protection tool, the first proposition is that an increase in the leftist bias of the government leads to an increase in the tariffs for labor intensive industries. In addition, we argue that antidumping is a substitute policy instrument for the industries which do not receive 
adequate protection via tariffs and the probability of observing an antidumping initiation decreases for the labor intensive industries with an increase in the government's leftist bias.

\section{Econometric Methodology and Data}

Our empirical analysis includes three sections in which we analyze the effect of political ideology on the tariff levels of the industries, the probability of industry level $\mathrm{AD}$ investigations, and the probability of an affirmative $\mathrm{AD}$ decision by government $\mathrm{AD}$ agencies, respectively.

\section{Estimation of Industry Level Tariffs}

Here we take a further step following DM (2005) and MJ (2004) and analyze the link between the governments' political partisanship and tariffs at the industry level. The theory outlined above predicts that there is a positive relationship between the left-wing ideology of the government and tariff for the industries with low $(K / L)$ given the fact that left-wing governments tend to redistribute income via policies to benefit labor. To test this prediction we estimate the following linear model:

$$
T r_{i h t}=\beta_{0}+\beta_{1} I_{\text {deology }} y_{i t}+\beta_{2} \text { Ideology }_{i t} * K / L_{i h t}+\beta_{3} K / L_{i h t}+Z_{i h t} \theta+\varepsilon_{i h t}
$$

where $T r_{i h t}$ denotes the weighted applied tariff level of three-digit ISIC industry $h$ in country $i,(K / L)_{i n}$ is the capital-labor ratio of the industry, 
Ideology $_{i t}$ denotes the degree of the government's leftist bias and $Z_{\text {int }}$ is a vector of control variables. ${ }^{3}$ Differentiating equation (8) with respect to Ideology $y_{i}$ we have

$$
\frac{\text { TTariff }_{\text {iht }}}{\text { dIdeology }_{\text {it }}}=\beta_{1}+\beta_{2} *(K / L)_{\text {iht }}
$$

The testable implication here is that $\beta_{1}>0$ and $\beta_{2}<0$ as pointed out in the theoretical model.

We also consider several control variables in our specifications. The first one is the share of industry output in total GDP which is related to the campaign contributions provided to the government elections in Grossman and Helpman (1994) model. We believe that industries with higher output share have higher ability to be politically organized and to lobby for protection. In addition, the competition from imports and the change in the total production of the industry would affect the protection level of the industry. To control for this effect, we use the average import and output growth of the industry in the last three years. We also control for the macroeconomic variables such as the percentage change in exchange rate, growth rate of GDP and the current account. All of these macroeconomic variables might be associated with the pressure against free trade. Following DM (2005), we also include the democracy level given the fact that politicians

\footnotetext{
${ }^{3}$ We use the natural logs of capital-labor ratios as in Dutt and Mitra (2005). Besides, this variable is lagged one period in all specifications of our empirical analysis to avoid the potential endogeneity between capital-labor ratio and protection.
} 
in democratic regime are more prone to pursue policies in favor of their electoral base. Moreover, we control for the WTO membership and the years of WTO membership of the country to capture the effect of WTO commitments and their trend on tariffs. Finally, we include country and three digit ISIC industry fixed effects to control for the unobservable country and industry specific variations.

\section{Estimation of Antidumping Initiations}

To empirically test the effect of partisanship on $\mathrm{AD}$ activity, linear probability model is used to estimate a country's three digit ISIC industry's decision of filing an $\mathrm{AD}$ petition. ${ }^{4}$ To do so, we aggregate the data on $\mathrm{AD}$ investigations from case-level to industry-level by matching the data on sixdigit Harmonized System product level AD information to data on production of three-digit ISIC industries. Our baseline model is:

$P\left(y_{1 i h t}=1\right)=\varphi\left(\phi_{0}+\phi_{1} I_{\text {deolog }} y_{i t}+\phi_{2} I_{\text {deology }} *(K / L)_{i n t}+\phi_{3}(K / L)_{i h t}+\right.$ $\phi 4 \mu i h t+\varepsilon) i h t$

(1.10)

where $y$ takes on a value of 1 if the industry filed at least one $\mathrm{AD}$ investigation in the given year and zero otherwise. 5 Similar to the tariff equation, we have the ideology, capital-labor ratio and their interaction in the

\footnotetext{
${ }^{4}$ Another strategy would be to use the number of AD filings as the dependent variable. However, it is impossible to find a predictor to separate the sampling and structural zeros in the dependent variable. See, Aggarwal (2007) for the same argument.

${ }^{5}$ Bown (2008) uses the same dependent variable and applies the same aggregation strategy combining the same data sources used in this paper.
} 
$\mathrm{AD}$ model. However, the expected signs of the coefficients for ideology variable and the interaction term are reversed because of the substitution argument of antidumping and tariffs. We hypothesize that an increase in the leftist orientation of the government makes labor intensive industries, which already received higher protection via tariffs, less likely to pursue an antidumping investigation.

We control for various other factors following the $\mathrm{AD}$ literature. For instance, WTO rules require domestic firms to provide evidence that dumping takes place on the one hand and the industry is materially injured on the other (WTO, 1995; Article 2.1 and 3.4). To control for these considerations, we include the average output and import growth of the industry in the last three years. The likelihood of filing an AD petition should increase with the fall in production and with more competition from imports. We also believe that industries with higher output have more ability to file an $\mathrm{AD}$ petition because of the fact that it is easier for them to cover the fixed costs associated with filing an $\mathrm{AD}$ initiation and follow the necessary process of an $\mathrm{AD}$ investigation. Consequently, we control for the share of industry output in a country's total GDP to capture the lobbying and the financial power of that particular industry. Following Francois and Niels (2006) and Knetter and Prusa (2003), we also control for macroeconomic indicators such as GDP growth, percentage change in the value of exchange rate and the current 
account balance. We are more likely to find an $\mathrm{AD}$ petition in periods of exchange rate appreciation, current account deficits and economic recession. In addition, as noted in Bown (2008), 1995 inception of WTO resulted in a common set of rules which are binding for all WTO members. Therefore, we also control for the WTO membership and the years of WTO membership to see the effect of WTO rules and enforcements and their trend on industries' $\mathrm{AD}$ activity. Moreover, although the primary interest of this paper is to investigate the effect of political ideology on tariff and $\mathrm{AD}$, including applied tariff as a control variable in the model of $\mathrm{AD}$ initiations also leads us to contribute to the earlier works of Moore and Zanardi (2008), Feinberg and Reynolds (2007) and Bown and Tovar (2008) which investigate the role of tariff liberalization in the face of the spread of antidumping usage. ${ }^{6}$ Finally, similar to the tariff equation, we also control for the democracy level in the countries.

\section{Estimation of Antidumping Outcomes}

We now turn our focus to the $\mathrm{AD}$ duty imposition decisions of $\mathrm{AD}$ authorities. National governments, when undertaking the AD process, seek considerable economic evidence on two issues: (1) whether there is international price discrimination, where the price of an exported good is less than its "fair value" in the market of the exporting country and (2) whether

\footnotetext{
${ }^{6}$ Following Zanardi (2008), we lag the applied tariff one period.
} 
this unfair pricing causes injury to the domestic market. Having reviewed the filings, $\mathrm{AD}$ authorities impose extra duties on the particular good in order to bring the value of the good closer to its fair value.

In order to quantify the effect of government's ideology on the affirmative $\mathrm{AD}$ outcome, we carry out a case-level estimation and pool the data of all $\mathrm{AD}$ investigations In addition, owing to the raw data of product level information on $\mathrm{AD}$ investigations, the case-level analysis enables us to include the six-digit Harmonized System tariff when providing an answer to the question whether tariff and antidumping duties are substitute or complement policy instruments from the perspective of the governments. The following linear probability model is estimated:

$P\left(y_{2 i c t}=1\right)=\eta\left(\gamma_{0}+\gamma_{1}\right.$ Ideology $_{i t}+\gamma_{2}$ Ideology $_{i t} *(K / L)_{i n t}+\gamma_{3}(K / L)_{i h t}+$

$\left.\gamma_{4} \mu_{i h} t+\varepsilon_{i h t}\right)$

where the binary dependent variable $Y_{2 i c t}$ is 1 if government authorities decide affirmatively to a specific $\mathrm{AD}$ case from industry $h$ and zero for all other outcomes such as negative, withdrawn and terminated. It should be noted that the ideology variable in (11) denotes the ideology of the government at the time of the final injury decision. Our hypothesis is that left-wing governments, which tend to increase the returns to labor, are more likely to decide affirmatively for $\mathrm{AD}$ cases of the industries that are labor intensive. Therefore, the predicted signs of the ideology variable and the 
interaction term are positive and negative respectively, as are in the tariff equation.

A serious problem in estimation $\mathrm{AD}$ outcomes is that the expected value of the dependent variable, the outcome of the $\mathrm{AD}$ petition, affects the sample size. This creates a potential sample selection bias in the set of $\mathrm{AD}$ initiations when we estimate the $\mathrm{AD}$ outcomes. ${ }^{7}$ As shown in Blonigen (2006), when deciding to file a petition, firms evaluate the decision rule where expected gains from filing a petition is greater than the fixed cost of filing. Therefore, firms pursue an $\mathrm{AD}$ petition only if

$$
E^{*}=p \cdot \pi-f>0
$$

where $p$ denotes the expected probability of an affirmative $\mathrm{AD}$ decision, $\pi$ denotes the expected gain from a successful outcome and $f$ denotes the fixed cost associated with filing a petition. Therefore, industries with smaller output share are less likely to follow an $\mathrm{AD}$ investigation because of the fixed cost involved. In order to remedy this potential sample selection bias, we also estimate $\mathrm{AD}$ outcomes using the Heckman (1979) selection model. The outcome equation for the governments' decision to impose duty becomes

$$
y_{2 i n t}=x_{i n t} \theta+u_{1}
$$

\footnotetext{
${ }^{7}$ Hansen (1990) and Bown (2006) also address the sample selection bias in the set of AD investigations.
} 
However, $Y_{2 i n t}$ is not observed for the industries for which the expected gain of the successful outcome does not exceed the fixed cost of filing associated with a petition. Our assumption is that $Y_{2 i n t}$ is only observed if

$$
w_{i h t} \theta+u_{2}>0
$$

In the Heckman selection model $x_{i n}$ and $w_{i n}$ are the vectors of explanatory variables to be estimated. Further, we assume that

$$
\left(\begin{array}{l}
u_{1} \\
u_{2}
\end{array}\right) \sim N\left\{\left(\begin{array}{l}
0 \\
0
\end{array}\right),\left[\begin{array}{ll}
1 & \rho \\
\rho & 1
\end{array}\right]\right\}
$$

Separate estimation of AD outcomes will yield biased estimates for the parameters, if $\rho \neq 0$. The Heckman model offers an estimation strategy which corrects the sample selection bias by treating the industries' decision to file an $\mathrm{AD}$ petition as the first stage selection equation and the governments' $\mathrm{AD}$ duty imposition decision as the second stage outcome equation.

In addition to all control variables in the previous $\mathrm{AD}$ analysis, the selection equation of the Heckman model has to contain at least one variable, which is not included in the outcome equation, to identify the selection equation. For this purpose, we use the number of establishments (NEST) in each industry, a proxy for firm concentration in the first stage selection equation. Studies such as Rodrik (1995) and Reynolds (2006) argue that it is harder for industries with more firms, or less concentration, to overcome the free rider problem to file a petition. On the other hand, an increase in the 
number of firms might be associated with an increase in the probability of observing $\mathrm{AD}$ investigations for the industries which is highly concentrated due to the competitive effect of such an increase on the price levels. This calls for modeling a possible non-linearity between the number of establishments and $\mathrm{AD}$ filings, which we do by adding a quadratic term of this variable in the first stage selection equation.

\section{Data}

We collected the data of output, import, gross fixed capital formation, number of workers, number of establishments and the tariff data of 28 threedigit ISIC industries from World Bank Trade, Production and Protection (TPP) database (Nicita and Olerreaga, 2006). The tariff variable we employ is the import weighted average applied tariffs for the 28 three-digit ISIC industries. Following the convention, the capital stocks $(K)$ of industries are calculated from investment series by the perpetual inventory equation:

$$
K_{t+1}=I_{t}+(1-\delta) K_{t}
$$

where $I_{t}$ is the gross fixed capital formation and $\delta$ is the depreciation rate. ${ }^{8}$ The initial capital stock $\left(K_{0}\right)$ is computed as $I_{0} /(\delta+g)$, where $g$ is the average geometric growth rate for the first ten years of available data. ${ }^{9}$

\footnotetext{
8 The depreciation rate is assumed to be 0.06 .

${ }_{9}^{9}$ See Caselli (2004).
} 
The data on product-level $\mathrm{AD}$ investigations and outcomes are obtained from Global Antidumping Database Version 5.0 (Bown, 2009) which provides detailed product-level information on $\mathrm{AD}$ filings and outcomes. This database provides the date of the initiation and final decision of $\mathrm{AD}$ case, the target country, the final decision of the AD authority as well as the HS codes of the products subject to filings. For industry level estimation, we matched the data on $\mathrm{AD}$ investigations at the six-digit Harmonized System product level to data on production in three-digit ISIC industries. For the case-level analysis, we pooled the data on all $\mathrm{AD}$ investigations and assigned each observation its three-digit ISIC code using the concordances in the TPP database.

For the political ideology variable, we utilize the Database of Political Institutions (Beck et al., 2008), which is updated annually and includes data for the period 1975 through 2006. This database provides qualitative information on the political position of the executive power for each country, in the form of leftist, centrist and rightist ideologies. Our continuous ideology variable, whose increase can be interpreted as an increase in the leftist orientation, takes on a value of 1,2 and 3 for the right-wing, center-wing and left-wing governments respectively. ${ }^{10}$ For the democracy index, we use

\footnotetext{
10 While we do not report in the paper, we also tried assigning a dummy variable for each ideology category and running the regressions with that measure in order to test for the robustness of the results. Our findings are insensitive to different treatment of the ideology measure.
} 
Freedom in the World Country Ratings, Freedom House's publication which was published in 1972 and reports the data on civil liberties and political rights for 193 countries. The democracy (political rights) index is such that more democratic countries are assigned a lower score than less democratic countries on a scale of 1 to 7 . We reversed the scores by subtracting each score from 8 so that more democratic countries take higher scores.

The data on WTO membership come from WTO website and the data on tariff of six-digit Harmonized System products are obtained from UNCTAD's TRAINS database which is accessed through The World Integrated Trade Solution (WITS) software developed by the World Bank. Finally, we use the database of United States Department of Agriculture (USDA) Economic Research Service for the data of exchange rate and World Development Indicators, 2005 for the data of GDP growth and the current account.

Table 1.1 and Table 1.2 provide the descriptive statistics and the data sources for the industry level and case-level analysis, respectively. We construct a balanced panel for the tariff and the $\mathrm{AD}$ estimations, which covers the time period between 1986 and 2001. However, the availability of 
the tariff, investment and labor data in TPP determines the sample of our analysis. $^{11}$

\section{Results}

Table 1.3 presents the estimation results of equation (8). Specification (1) reports the results without any controls and fixed effects. Specification (2) includes political, macroeconomic and other industry controls. Specifications (3) documents the estimates when fixed effects are also included for the unobservable country or/and industry variations. Focusing first on the variables of interest in Table 1.3, we see that the coefficient of the ideology variable and the coefficient of the interaction term are positive and negative respectively. Both of them are also statistically significant in all specifications. As shown, there is a positive relationship between the level of tariffs and the government's leftist orientation for low levels of capital-labor ratio. As the capital-labor ratio increases, the negative interaction term dominates the positive ideology coefficient.

In terms of control variables, consistent with the political influence hypothesis, higher output share of the industry is associated with lower tariffs. However, output and import growth of the industry are insignificant

\footnotetext{
${ }^{11}$ The reason why we do not include the European Union (EU) countries is that AD decisions in the European Union are evaluated by the Trade Directorate of the European Commission which makes it ambiguous to analyze which country's ideology matters. In addition, as provided by Global AD database (Bown, 2009), firms from different countries jointly file in most of the AD cases of the EU. Furthermore, Indonesia is excluded from our sample because the ideologies of the political parties of Indonesia are unspecified in DPI database.
} 
when fixed effects are included. The growth rate of GDP has a significant positive effect on the industry tariff, which implies that it is easier for governments to increase the tariffs in a period of economic growth, reason being that the increase in prices hurts consumers less than it does in a period of recession. However, the other two macroeconomic factors, current account and exchange rate, has no significant effect on tariffs. In addition, the effect of democracy on trade liberalization is positive in our preferred specification in which we have country and industry fixed effects. This finding also supports the earlier work of Milner and Kubota (2005) which shows that reduced trade barriers are associated with a movement toward democracy. ${ }^{12}$. Finally, the WTO membership reduced the tariffs but the coefficient estimate of the "years of WTO membership" suggests that the liberalization effect of the WTO decreases as each year passes.

Turning to the industries' decision to file an $\mathrm{AD}$ investigation, we report the estimates of the linear probability model in equation (10) in Table 1.4. Specifications (1) shows the results without any controls but the control variables and fixed effects are included in all other specifications. As opposed to results in Table 1.3, the negative coefficient of the ideology variable and the positive coefficient of the interaction term in all specifications support our prediction that the likelihood of an industry's decision to pursue an $\mathrm{AD}$ investigation decreases for labor intensive industries when the government's

\footnotetext{
${ }^{12}$ Milner and Kubota (2005) use a different proxy for democracy.
} 
leftist orientation increases. The rationale behind this finding is that an increase in the leftist orientation of the government makes labor intensive industries, which receive higher protection via tariffs, less likely to file an $\mathrm{AD}$ petition. The reversed signs of the ideology and its interaction in Tables 1.3 and 1.4 also go along with the substitution hypothesis between trade liberalization and $\mathrm{AD}$ use. Once again, the significance of the ideology variable and the interaction term is insensitive to inclusion of control variables and fixed effects.

In accordance with the lobbying and financial power argument, industries with higher output share are more likely to file an $\mathrm{AD}$ investigation. Besides, with respect to the WTO requirements, an increase in industry output is associated with a decrease in the probability of observing an $\mathrm{AD}$ initiation for an industry. Both the output share and the output growth are significant in all specifications. In addition, consistent with the previous studies in $\mathrm{AD}$ literature, appreciation of the local currency, the periods of economic recession and current account deficit are associated with an increase in the likelihood of $\mathrm{AD}$ use. However, we do not find any significant effect of import growth of the industry on $\mathrm{AD}$ filings when controlling for country and industry fixed effects. Moreover, increase in the democratization of the country makes domestic firms more likely to pursue an $\mathrm{AD}$ investigation. This can be attributed to the higher expected probability 
of wining an $\mathrm{AD}$ case because of better institutions in a democratic regime. This result might also implicate that industries in democratic countries have easier access to the government agencies which reduces their filing costs associated with an $\mathrm{AD}$ petition. The liberalization efforts of democracies might also rush industries toward filing $\mathrm{AD}$ cases. The positive sign of the coefficient on the WTO membership shows the triggering effect of common set of $\mathrm{AD}$ rules on the industries' $\mathrm{AD}$ initiations after the 1995 inception of WTO. On the other hand, the estimate of years of WTO membership shows that the effect of WTO on industries' AD filings was higher in the first years of its inception and this effect is decreasing over time.

We now turn to the results of government's decision to impose $\mathrm{AD}$ duty. In Table 1.5, we report the estimates when the data of product level AD information is pooled and each observation is matched with its three-digit ISIC code. The availability of the six-digit HS tariff data determines the sample size here. In line with the earlier discussion, the positive estimate of the ideology variable and the negative estimate of interaction term demonstrate that an increase in the leftist bias of the government is associated with an increase in the likelihood of an affirmative outcome for the industries operating at low capital-labor ratio. The estimations of governments' decision to impose $\mathrm{AD}$ duty result in the same pattern of signs for the variables of interest both in tariff and $\mathrm{AD}$ outcome equations. In terms of control variables, we find that petitions from larger industries are 
associated with a higher probability of a successful outcome. Consistent with the WTO's requirements, industries facing more competition from imports are more likely to grant $\mathrm{AD}$ protection, as well as the industries experiencing a depression in production. Finally, we do not find a significant effect of the macroeconomic determinants on the probability of observing a successful AD case.

Tables 1.6 documents the results of the Heckman selection model where the first stage is the industries' decision to file an $\mathrm{AD}$ petition and the second stage is the governments' $\mathrm{AD}$ duty imposition outcome whether it is affirmative. Once again, the primary variables of interest are ideology measure and its interactions. Despite the small variation in the dependent variable in the second stage, the estimates in column (2) of Table 1.6 support the results we obtained in the separate estimations of $\mathrm{AD}$ outcomes. Moreover, the altered sign of the ideology variable and its interaction in the first and second stage is in line with the previous findings of $\mathrm{AD}$ investigations. The number of establishments which is used to identify the selection model is also significant in both tables. The coefficients on the variables NEST and NEST ${ }^{2}$ imply that an increase in the number of firms in the industry is associated with an increase in the probability of observing an $\mathrm{AD}$ investigation for smaller industries. However the negative coefficient of the quadratic term, $\mathrm{NEST}^{2}$, indicates that very large industries are less likely 
to file an $\mathrm{AD}$ petition. ${ }^{13}$ This inverted-U shaped relationship between the firm concentration and $\mathrm{AD}$ filings implies that the competition effect which is a consequence of an increase in the number of firms creates an incentive for the firms to file an $\mathrm{AD}$ petition; however, as the number of firms keeps increasing, the free rider problem dominates such incentives. In addition, firms might be reluctant to file a petition in that case given the fact that per firm benefit of a successful outcome will be reduced for very large industries. ${ }^{14}$ In addition to all these points, the same signs for the coefficients of the ideology variable and its interactions both in tariff and $\mathrm{AD}$ outcome models imply that tariff and antidumping duties are complements in terms of governments' trade policy. Therefore, the redistribution argument from capital to labor due to the pro-labor policies of left-wing government is supported both in the models of tariff and AD duty imposition.

\section{Conclusion}

To our knowledge, this study is the first attempt to examine the effect of political ideology of the governments on $\mathrm{AD}$ protection. Following the political economy literature which addresses the effect of partisan preferences of governments on trade policy, we first show evidence that the predictions of the ideology based model of trade protection is also supported

\footnotetext{
${ }^{13}$ We also tried excluding the quadratic term in the selection equation. However, it resulted in insignificant estimate of the number of establishments.

${ }^{14}$ See Reynolds (2006).
} 
at the industry level. Consistent with the redistributive mechanism of protection, we find that an increase in the leftist extent of the government increases the returns to labor which in turns increases the tariff of the labor intensive industries. Besides, matching the data on three-digit ISIC industries' production and protection with the detailed product level information on $\mathrm{AD}$ filings, we demonstrate that in the periods of left wing governments, an increase in the labor intensity of the industry is associated with a decrease in the likelihood of observing an $\mathrm{AD}$ initiation from that industry, which already grants higher protection in the form of tariffs. The substitutability of tariff and $\mathrm{AD}$ usage is supported not only with this result but also with the robust negative effect of applied tariffs on the probability of AD filings. In addition, our results suggest the effect of political ideology on the governments' decision to impose $\mathrm{AD}$ duty. The empirical results of both separate estimation and two-stage Heckman model, which corrects the potential sample selection bias, confirm that the probability of a successful $\mathrm{AD}$ investigation increases in labor intensity of that industry when there is a left-wing government in power. Our last finding also speaks to the complementarity of tariff and $\mathrm{AD}$ duties from the governments' view. Our results are robust to controlling for country and industry fixed effects and also insensitive to controlling for several factors which is pointed out in the existing literature. 
Table. 1.1 Summary Statistics (Industry level)

\begin{tabular}{llllll}
\hline Variable & Mean & Max & Min & Standard deviation & N \\
AD Initiation & 0.096 & 1 & 0 & 0.295 & 3500 \\
AD affirmative & 0.724 & 1 & 0 & 0.447 & 338 \\
Ideology & 1.936 & 3 & 1 & 0.927 & 3500 \\
K/L (log) & 10.161 & 16.629 & 4.702 & 1.257 & 3355 \\
Output share & 0.936 & 13.228 & 0.001 & 1.331 & 3318 \\
Output growth§ & 0.091 & 4.820 & 0.613 & 0.186 & 3402 \\
Import growth§ & 0.508 & 180.498 & 0.986 & 5.562 & 3472 \\
GDP growth & 4.090 & 12.822 & -11.7 & 3.941 & 3500 \\
Exchange rate & 0.950 & 69.458 & 0.151 & 6.460 & 3472 \\
Current account & 24.656 & 40.371 & -413.442 & 65.385 & 3500 \\
Number of establishments & 1795 & 95664 & 1 & 4.269 & 2752 \\
WTO membership & 0.384 & 1 & 0 & 0.486 & 3500 \\
Years of WTO membership & 1.392 & 7 & 0 & 2.109 & 3500 \\
Democracy & 5.576 & 7 & 2 & 1.292 & 3500 \\
Tariff (3 digit) & 12.499 & 337.16 & 0 & 19.288 & 1544 \\
\hline
\end{tabular}

- * variable scaled down by $10^{6}$

- $\S$ Average percentage change, three years before $t$.

- indicates the summary statistics when $\mathrm{AD}$ initiation=1 
Table 1.2. Descriptive Statistics (Case level)

\begin{tabular}{llllll} 
Variable & Mean & Max & Min & Standard deviation & N \\
\hline AD affirmative & 0.596 & 1 & 0 & 0.490 & 1328 \\
Ideology & 1.711 & 3 & 1 & 0.946 & 1328 \\
K/L (log) & 11.102 & 13.157 & 8.276 & 0.932 & 1249 \\
Output share & 1.598 & 12.357 & 0.022 & 1.590 & 1246 \\
Output growth§ & 0.047 & 1.908 & -0.561 & 0.179 & 1242 \\
Import growth & 0.080 & 4.033 & -0.507 & 0.270 & 1324 \\
GDP growth & 3.307 & 9.486 & -6.854 & 2.989 & 1328 \\
Exchange rate & 0.092 & 1.638 & -0.157 & 6.460 & 1328 \\
Current account & -60.680 & 40.371 & -413.442 & 102.243 & 1328 \\
WTO membership & 0.427 & 1 & 0 & 0.494 & 1328 \\
Years of WTO membership & 1.878 & 7 & 0 & 2.506 & 1328 \\
Democracy & 6.190 & 7 & 3 & 1.240 & 1328 \\
Tariff (6 digit) & 12.585 & 65 & 0 & 11.654 & 998 \\
\hline
\end{tabular}

- $\quad$ * variable scaled down by 10

- $\quad \S$ Average percentage change, three years before $t$. 
TABLE 1.3. Regression Estimates of Three-Digit ISIC Tariff

\section{(1)}

Ideology $y_{i t}$

Ideology $y_{i t} *(K / L)_{i h t}$

$(K / L)_{i h t}$

Political

determinants

Output share

Import growth

Output growth

WTO membership

Years of WTO

membership

Democracy

Macroeconomic

factors

\begin{tabular}{|c|c|c|c|}
\hline \multicolumn{2}{|l|}{$G D P$ growth } & $\begin{array}{l}0.916 \\
(5.98) * * *\end{array}$ & $\begin{array}{l}0.570 \\
(6.38)^{* * * *}\end{array}$ \\
\hline \multirow{2}{*}{\multicolumn{2}{|c|}{ Exchange rate }} & -2.470 & 0.500 \\
\hline & & $(1.49)$ & $(0.52)$ \\
\hline \multicolumn{2}{|l|}{ Current Account } & 0.033 & 0.007 \\
\hline Country fixed effects & No & No & Yes \\
\hline Industry fixed effects & No & No & Yes \\
\hline Observations & 1426 & 1329 & 1329 \\
\hline
\end{tabular}

35.487

$(3.67)^{* * *}$

$-3.111$

$(3.53)^{* * *}$

0.478

(0.43)
(2)

33.614

$(3.42)^{* * *}$

$-2.737$

$(3.06)^{* * *}$

0.702

$(0.62)$
(3)

15.737

$-1.182$

$(2.03)^{* *}$

$-1.529$

(0.97)
$(2.47)^{* *}$

$\begin{array}{ll}-0.933 & -0.600 \\ (2.66)^{* * *} & (2.37)^{* *} \\ 0.076 & 0.014 \\ (3.98)^{* * *} & (0.73) \\ -0.051 & -0.058 \\ (0.03) & (0.76) \\ -22.140 & -8.237 \\ (5.01)^{* * *} & (4.09)^{* * *} \\ 1.597 & 0.349\end{array}$

$(4.81)^{* * *}$

$(2.00)^{* *}$

$-0.129$

$-2.507$

(0.26)

$(3.45)^{* * *}$$$
\text { (0.26) }
$$

$(5.98)^{* * *}$

$(6.38)^{* * *}$

$-2.470$

0.500

(1.49)

(0.52)

0.033

0.007

No

No 
Binary dependent variable $=1$ if the industry filed an $\mathrm{AD}$ petition

\begin{tabular}{|c|c|c|c|c|}
\hline & $(1)$ & $(2)$ & (3) & $(4)$ \\
\hline Ideology $y_{i t}$ & $\begin{array}{l}-0.077 \\
(2.18)^{* * *}\end{array}$ & $\begin{array}{l}-0.103 \\
(2.78)^{* * *}\end{array}$ & $\begin{array}{l}-0.142 \\
(3.50)^{* * *}\end{array}$ & $\begin{array}{l}-0.142 \\
(2.07)^{* *}\end{array}$ \\
\hline Ideolog $y_{i t} *(K / L)_{i h t}$ & $\begin{array}{l}0.009 \\
(2.37)^{* *}\end{array}$ & $\begin{array}{l}0.011 \\
(2.99)^{* * *}\end{array}$ & $\begin{array}{l}0.014 \\
(3.47)^{* * *}\end{array}$ & $\begin{array}{l}0.016 \\
(2.40)^{* *}\end{array}$ \\
\hline$(K / L)_{i h t}$ & $\begin{array}{l}-0.003 \\
(0.32)\end{array}$ & $\begin{array}{l}-0.026 \\
(3.06)^{* * *}\end{array}$ & $\begin{array}{l}-0.035 \\
(3.94)^{* * *}\end{array}$ & $\begin{array}{l}-0.039 \\
(2.92)^{* * *}\end{array}$ \\
\hline \multicolumn{5}{|l|}{ Political determinants } \\
\hline Output share & & $\begin{array}{l}0.031 \\
(5.81)^{* * *}\end{array}$ & $\begin{array}{l}0.026 \\
(3.81)^{* * *}\end{array}$ & $\begin{array}{l}0.037 \\
(3.87)^{* * *}\end{array}$ \\
\hline Import growth & & $\begin{array}{l}0.001 \\
(4.97)^{* * *}\end{array}$ & $\begin{array}{l}0.001 \\
(0.32)\end{array}$ & $\begin{array}{l}0.001 \\
(0.21)\end{array}$ \\
\hline Output growth & & $\begin{array}{l}-0.035 \\
(1.70)^{*}\end{array}$ & $\begin{array}{l}-0.048 \\
(2.29)^{* *}\end{array}$ & $\begin{array}{l}-0.035 \\
(1.77)^{*}\end{array}$ \\
\hline WTO membership & & $\begin{array}{l}0.222 \\
(3.83)^{* * *}\end{array}$ & $\begin{array}{l}0.186 \\
(3.24)^{* * *}\end{array}$ & $\begin{array}{l}0.019 \\
(0.18)\end{array}$ \\
\hline Years of WTO membership & & $\begin{array}{l}-0.027 \\
(5.11)^{* * *}\end{array}$ & $\begin{array}{l}-0.023 \\
(4.50)^{* * *}\end{array}$ & $\begin{array}{l}-0.003 \\
(0.29)\end{array}$ \\
\hline Democracy & & $\begin{array}{l}0.015 \\
(3.24)^{* * *}\end{array}$ & $\begin{array}{l}0.014 \\
(2.03)^{* *}\end{array}$ & $\begin{array}{l}0.010 \\
(0.76)\end{array}$ \\
\hline \multicolumn{5}{|l|}{ Macroeconomic factors } \\
\hline$G D P$ growth & & $\begin{array}{l}-0.008 \\
(5.14)^{* * *}\end{array}$ & $\begin{array}{l}-0.004 \\
(2.20)^{* *}\end{array}$ & $\begin{array}{l}-0.004 \\
(1.06)\end{array}$ \\
\hline Exchange rate & & $\begin{array}{l}-0.030 \\
(2.53)^{* *}\end{array}$ & $\begin{array}{l}-0.031 \\
(2.18)^{* *}\end{array}$ & $\begin{array}{l}0.001 \\
(0.02)\end{array}$ \\
\hline Current Account & & $\begin{array}{l}-0.000 \\
(1.72)^{*}\end{array}$ & $\begin{array}{l}-0.001 \\
(2.81)^{* * *}\end{array}$ & $\begin{array}{l}0.001 \\
(3.09)^{* * *}\end{array}$ \\
\hline Tariff (3 digit) & & & & $\begin{array}{l}-0.001 \\
(1.66)^{*}\end{array}$ \\
\hline Country fixed effects & No & No & Yes & Yes \\
\hline Industry fixed effects & No & No & Yes & Yes \\
\hline Observations & 3022 & 2954 & 2954 & 1425 \\
\hline
\end{tabular}


Binary dependent variable $=1$ if the government imposed

AD duty

\begin{tabular}{|c|c|c|c|}
\hline & (1) & (2) & (3) \\
\hline Ideology $y_{i t}$ & $\begin{array}{l}0.385 \\
(1.93)^{*}\end{array}$ & $\begin{array}{l}1.025 \\
(3.71)^{* * *}\end{array}$ & $\begin{array}{l}0.735 \\
(2.20) * *\end{array}$ \\
\hline Ideolog $y_{i t} *(K / L)_{i h t}$ & $\begin{array}{l}-0.037 \\
(2.07)^{* *}\end{array}$ & $\begin{array}{l}-0.086 \\
(3.57)^{* * *}\end{array}$ & $\begin{array}{l}-0.062 \\
(2.10)^{* *}\end{array}$ \\
\hline$(K / L)_{i h t}$ & $\begin{array}{l}0.041 \\
(0.98)\end{array}$ & $\begin{array}{l}0.118 \\
(2.08)^{* *}\end{array}$ & $\begin{array}{l}0.001 \\
(0.01)\end{array}$ \\
\hline \multicolumn{4}{|l|}{$\begin{array}{l}\text { Political } \\
\text { determinants }\end{array}$} \\
\hline Output share & & $\begin{array}{l}0.024 \\
(1.88)^{*}\end{array}$ & $\begin{array}{l}0.025 \\
(1.72)^{*}\end{array}$ \\
\hline Import growth & & $\begin{array}{l}0.094 \\
(1.38)\end{array}$ & $\begin{array}{l}0.141 \\
(1.87)^{*}\end{array}$ \\
\hline Output growth & & $\begin{array}{l}-0.752 \\
(4.80)^{* * *}\end{array}$ & $\begin{array}{l}-0.587 \\
(3.29) * * *\end{array}$ \\
\hline WTO membership & & $\begin{array}{l}-0.108 \\
(1.31)\end{array}$ & $\begin{array}{l}-0.082 \\
(0.95)\end{array}$ \\
\hline $\begin{array}{l}\text { Years of WTO } \\
\text { membership }\end{array}$ & & 0.066 & 0.102 \\
\hline & & $(2.03)^{* *}$ & $(2.57)^{* *}$ \\
\hline Democracy & & $\begin{array}{l}0.026 \\
(0.84)\end{array}$ & $\begin{array}{l}0.046 \\
(0.50)\end{array}$ \\
\hline \multicolumn{4}{|l|}{$\begin{array}{l}\text { Macroeconomic } \\
\text { factors }\end{array}$} \\
\hline GDP growth & & $\begin{array}{l}0.005 \\
(0.43)\end{array}$ & $\begin{array}{l}-0.006 \\
(0.55)\end{array}$ \\
\hline Exchange rate & & $\begin{array}{l}0.027 \\
(0.14)\end{array}$ & $\begin{array}{l}-0.114 \\
(0.58)\end{array}$ \\
\hline Current Account & & $\begin{array}{l}0.000 \\
(0.43)\end{array}$ & $\begin{array}{l}0.000 \\
(0.52)\end{array}$ \\
\hline Tariff (6 digit) & & $\begin{array}{l}0.006 \\
(1.91)^{*}\end{array}$ & $\begin{array}{l}0.010 \\
(2.52)^{* *}\end{array}$ \\
\hline Country fixed effects & No & No & Yes \\
\hline Industry fixed effects & No & No & Yes \\
\hline Observations & 1195 & 898 & 898 \\
\hline
\end{tabular}


TABLE 1.6. Heckman Selection Model of Antidumping Investigations and Outcomes

\begin{tabular}{|c|c|c|}
\hline & $\begin{array}{l}\text { Stage } 1 \\
\text { Selection Equation } \\
\text { Binary dependent } \\
\text { variable=1 } \\
\text { if industry files an } \\
\text { AD petition }\end{array}$ & $\begin{array}{l}\text { Stage } 2 \\
\text { Regression Equation } \\
\text { Binary dependent variable=1 } \\
\text { if government imposes } \mathrm{AD} \\
\text { measure }\end{array}$ \\
\hline Ideology & $\begin{array}{l}-0.931 \\
(1.67)^{*}\end{array}$ & $\begin{array}{l}1.231 \\
(1.67)^{*}\end{array}$ \\
\hline Ideology ${ }^{*} K / L$ & $\begin{array}{l}0.108 \\
(2.14)^{* *}\end{array}$ & $\begin{array}{l}-0.141 \\
(2.07)^{* *}\end{array}$ \\
\hline$K / L$ & $\begin{array}{l}-0.292 \\
(2.39)^{* *}\end{array}$ & $\begin{array}{l}0.202 \\
(1.68)^{*}\end{array}$ \\
\hline Output share & $\begin{array}{l}0.174 \\
(4.13)^{* * *}\end{array}$ & $\begin{array}{l}0.023 \\
(0.35)\end{array}$ \\
\hline Import growth & $\begin{array}{l}0.097 \\
(1.28)\end{array}$ & $\begin{array}{l}0.718 \\
(3.39)^{* * *}\end{array}$ \\
\hline Output growth & $\begin{array}{l}-0.450 \\
(1.03)\end{array}$ & $\begin{array}{l}-0.907 \\
(2.22)^{* *}\end{array}$ \\
\hline WTO membership & $\begin{array}{l}-1.058 \\
(0.56)\end{array}$ & $\begin{array}{l}2.200 \\
(1.89)^{*}\end{array}$ \\
\hline Years of WTO membership & $\begin{array}{l}0.063 \\
(0.32)\end{array}$ & $\begin{array}{l}-0.164 \\
(1.44)\end{array}$ \\
\hline Democracy & $\begin{array}{l}0.044 \\
(0.34)\end{array}$ & $\begin{array}{l}-0.154 \\
(1.10)\end{array}$ \\
\hline GDP growth & $\begin{array}{l}-0.098 \\
(2.40)^{* *}\end{array}$ & $\begin{array}{l}-0.074 \\
(2.16)^{* *}\end{array}$ \\
\hline Exchange rate & $\begin{array}{l}-0.333 \\
(0.46)\end{array}$ & $\begin{array}{l}-1.509 \\
(2.77)^{* * *}\end{array}$ \\
\hline Current account & $\begin{array}{l}-0.000 \\
(1.45)\end{array}$ & $\begin{array}{l}0.000 \\
(1.20)\end{array}$ \\
\hline Tariff (3 digit) & $\begin{array}{l}-0.033 \\
(5.28)^{* * *}\end{array}$ & $\begin{array}{l}0.013 \\
(1.00)\end{array}$ \\
\hline$N E S T$ & $\begin{array}{l}0.064 \\
(2.27)^{* * *}\end{array}$ & \\
\hline$N E S T^{2}$ & $\begin{array}{l}-0.006 \\
(2.42)^{* *}\end{array}$ & \\
\hline Country fixed effect & Yes & Yes \\
\hline Industry fixed effect & Yes & Yes \\
\hline Observations & 1030 & 159 \\
\hline
\end{tabular}




\section{CHAPTER 2}

\section{THE ANATOMY OF TRADE DEFLECTION}

\section{Introduction}

Antidumping (AD) has become a favorite remedy for the firms which seek protection. These preferences have increased especially after the substantial tariff liberalization countries have undergone after the World Trade Organization (WTO)'s rules and enforcements. Most tariffs are governed by trade agreements; however countries can receive protection by the use of alternative safeguards. Among these alternative protection instruments, $\mathrm{AD}$ has become the most frequently used and the most influential one. ${ }^{15}$ Today, more than 40 members of the WTO have implemented $\mathrm{AD}$ law and they filed more than 4,000 cases in the last 20 years.

Ideally, $\mathrm{AD}$ aims to prevent predatory dumping, a situation where international price discrimination drives the domestic firms out of the market. However, because of the imperfect observability of fair and unfair pricing, it is hard to identify whether AD duties are motivated by dumping or

\footnotetext{
15 Antidumping duties, which are defined in GATT Article VI, are easier to use compared to other safeguards such as emergency protection of a threatened industry (GATT Article XIX), exceptions for health or safety concerns (GATT Article XX) and restrictions for national security (GATT Article XXI).
} 
by the domestic pressures towards protection. Much of the evidence suggests that $\mathrm{AD}$ protection is abused to protect inefficient import competing firms. ${ }^{16}$

Similar to other discriminatory adjustments in trade policy, AD duties not only affect the trade flows of the named and the duty imposer country but also affect the trade flows of the third countries. ${ }^{17}$ This effect can occur in the form of trade diversion, a change in the source of origin for a country's imports caused by a change in importer's trade policy, or in the form of trade deflection, a change in the destination of exports due to an increase in trade restriction imposed in a particular export market. One of the more wellknown pieces of evidence on trade diversion is from Prusa (2001) who shows that US imposition of an $\mathrm{AD}$ duty increases the imports from the countries which are not named in the investigation. Ganguli (2008) and Konings et al. (2001) also arrive at the same conclusion analyzing the AD investigations of India and European Union respectively. The idea of trade deflection in the AD literature, on the other hand, was first introduced by Bown and Crowley (henceforth BC) (2007). In their product-level analysis, they find that US imposition of import restrictions in the form of an $\mathrm{AD}$ duty resulted in Japanese exports surging to non-US countries. Their findings suggest that

\footnotetext{
${ }^{16}$ See Konings and Vandenbusche (2008) and Aggarwal (2007).

17 A 'discriminatory' trade policy is the one in which a country imposes different trade restrictions to imports from different exporting countries. Two examples in this category are the preferential trade agreements and antidumping duties. On the contrary, a 'nondiscriminatory' trade policy is the one that is applied equally to all importers.
} 
exporters which suffer discriminatory trade restrictions in a country strive to find alternative markets to sell their products.

This study employs a unique three dimensional Brazilian firm-level data of exports between 1994 and 2000 to investigate the effect of $\mathrm{AD}$ duties, which targets Brazilian exporters, on the trade flows of the targeted firms to alternative markets in order to pave the way for a more detailed exploration of trade deflection which has become an important issue in the WTO and other Custom Unions' framework. We believe that analyzing the firm-level responses of $\mathrm{AD}$ duties on trade deflection will give us a better understanding of which destinations are potential export markets to deflect trade for the firms whose products are targeted by $\mathrm{AD}$ measures. Special attention is given to the ongoing debate in the international trade literature about the role of sunk start-up costs in the export market and the previous trading relationship of the firms. We investigate whether this past trading relationships to different countries affect trade deflection. Our analysis not only focuses on the intensive margin, increase in the volume of deflected trade arising from existing exporter-product combinations, but also on the extensive margin, increase in the new exporter-product combinations in alternative markets.

One of the outcomes associated with trade deflection is that a third country, which experiences a substantial import growth, might face pressure 
to react with a trade remedy of its own. For instance, as noted in BC (2007), the imposition of safeguard protection on steel products by European Union (EU), Chile, China, Czech Republic, Hungary and Venezuela between 2002 and 2003 stemmed from the earlier safeguards imposed by the US on steel. These countries believed that increase in the import restrictions of steel industry in the US lead to a gravitation of steel to their domestic market from the rest of the World. Hence, trade deflection contributes to the proliferation of worldwide AD filings, which in turns causes a depression in global trade. Moreover, World Trade Organization (WTO) section 16.8 allows a WTO member to impose a "China safeguard" on a product imported from China if the same product has already been targeted by another WTO member. Although this China-specific radical section is built on the threat that one country's imposition of import restriction against China deflects Chinese exports to alternative markets, empirical findings in BC (2010) suggest no systematic evidence of trade deflection for Chinese products targeted by US AD duties. Another concern associated with trade deflection is the practice of deliberately exporting goods to one country through a transit country in order to avoid import taxes. To guard against this type of exporting behavior, countries engaging in regional trade agreements use protocols for intra-regional trade in order to make sure that particular product originates from within the region. ${ }^{18}$

${ }^{18}$ See, Article 12 of The Common Market for Eastern and Southern Africa (COMESA). 
As there is no evidence of trade deflection at the product-level in China, BC (2010) also mentions that this could relate to the fact that China is a "new" entrant to the global trading system and Chinese firms have not yet set up necessary networks to deflect trade to alternate markets. ${ }^{19}$ However plausible their argument is, the product-level feature of their dataset does not allow them to explore the linkage between firms' previous exporting status in different markets and trade deflection. It is highly likely that Japanese firms which were serving more markets compared to their Chinese counterparts could deflect their trade to alternative destinations. In addition, some Chinese firms might have deflected their shipments to some of their trading partners, which would not be captured when the exports are aggregated to product level. In the presence of sunk start-up costs of exporting, it is difficult for the exporters to sell their products in alternative markets if they have not setup ongoing trading relationships in multiple markets. This argument is impossible to analyze without breaking down the firm exports by exported products and export destinations. In this regard, our rich dataset provides a unique opportunity to explore the variation in exports within firm across different destinations when there is a change in trade barrier for a particular product.

\footnotetext{
19 China granted membership in the WTO in 2001 and BC (2010) investigates the pre-
} accession period of China to WTO. 
It should be highlighted that $\mathrm{AD}$ duties provide a useful way of examining trade deflection. Antidumping duties yield substantial changes in trade flows given the fact that they are on average 10 to 20 times higher than the most favored nation (MFN) tariffs. ${ }^{20}$ Besides, $\mathrm{AD}$ duty is a product and a market specific trading cost for a firm. For example, if Mexican AD agencies impose an $\mathrm{AD}$ duty on Brazilian cotton shirt exporters, neither the other textile shirt exporters of Brazil nor the cotton shirt exporters of Argentina will be affected by this discriminatory policy adjustment. Hence, if a firm sells multiple products to a destination, it burdens paying $\mathrm{AD}$ duties only for that particular product which is targeted by the importer country. Since our analysis is based on attractive source of variation in the value of exports within firm-product combinations across export destinations, these product specific shocks for the firms in different export markets perfectly fits perfectly into our research question. Alongside this, Brazil is a well-suited country for such an analysis for number of reasons. First, as mentioned earlier, highly disaggregated firm-level data of Brazilian exports makes Brazil an outstanding case for this research. Second, Brazilian exported products were frequently targeted by $\mathrm{AD}$ duty over the period of our sample. There are $51 \mathrm{AD}$ cases filed against Brazil in this period, 40 of which resulted affirmatively. Moreover, these affirmative cases correspond to 120 unique sixdigit HS products. Finally, countries which imposed AD duty on Brazilian

20 See Prusa (2001). 
exported products accounts for almost $50 \%$ of the Brazil's total exports in1997. This allows us to expect a dramatic impact of AD duties imposed by these countries on the trade flows of Brazilian firms to third countries. Table 2.1 documents the products subject to $\mathrm{AD}$ duties and the duty imposing countries between 1994 and 2000 .

Our main findings in this study can be summarized as follows. Imposition of an $\mathrm{AD}$ duty on Brazilian HS six-digit products leads to a 25$33 \%$ increase in the firms' exports of the particular product to alternative countries where the firms previously exported the same product. Besides, it results in a 9\% increase in the firms' exports of the particular product to the countries where the firms exported another product. On the contrary, there is no significant effect of $\mathrm{AD}$ duties on the exports of the particular product to alternative countries the firm did not serve before. Further, exploring the extensive margin of trade deflection, we demonstrate that imposition of an AD duty against Brazilian exported products increases the probability of the targeted firms to introduce the particular product to a new market they previously served. When targeted by an $\mathrm{AD}$ duty in an export market, a firm's probability to start exporting the "duty imposed product" in an alternative destination increases by $8-10 \%$ if the firm already exported to that destination. However, we find no such evidence for the countries to which the firm did not export before. 
These findings shed light on the role of the past trading relationships on trade deflection and strongly support the sunk start-up costs argument on the heterogeneity of trade deflection to different countries. In line with the earlier studies on the entry to international markets with sunk $\operatorname{costs}^{21}$, the results obtained employing the export data of Brazilian firms suggests that firms are more willing to deflect their shipments to their ongoing trading partners instead of starting to export to a different destination in order to avoid paying the market specific start-up costs such as learning the bureaucratic procedures of exporting to a country. ${ }^{22}$ In addition, for the countries that the firm served before, the magnitude of trade deflection is found to be higher to the ones the firm exported the same product compared to the ones the firm exported another product. This heterogeneity in the results for the firms, which have different types of product-level trading relationships in an export destination, can be attributed to the productmarket specific start-up costs such as adapting the product in a particular destination.

To date, empirical evidence using firm-level data on $\mathrm{AD}$ policy is scarce. Konings and Vandenbussche (henceforth KV) (2008) estimate the effect of antidumping protection on the productivity of domestic import-

\footnotetext{
${ }^{21}$ See Melitz (2003) and Roberts and Tybout (1997)

22 One example in this category is the "Importer Security Filing" rule which recently went into effect in the US.
} 
competing firms in the EU. Belderbos (1997) illustrates the relationship between EU and US antidumping measures and foreign direct investment through a micro-econometrical analysis of Japanese firms' plant establishments in the electronics industry. In a noticeably detailed analysis, Pierce (2009) investigates the plant-level responses to AD measures for the protected plants in the US. KV (2009) remains the only firm-level study of $\mathrm{AD}$ policy to analyze the value of export sales and the extensive margin of exports. Although related, our paper conceptually distinguishes from KV (2009) for two reasons. First, their study focuses on the effect of France's own imposed $\mathrm{AD}$ duties on the exports of the protected firms, whereas we analyze the effect of $\mathrm{AD}$ duties which targets the exporters in the international market. Second, they exploit a two dimensional panel which does not differentiate the product categories for the firms which exports multiple products. Whereas, with a unique three dimensional panel data for firm, product and destinations, the empirical analysis carried out in this paper is a significant improvement over the previous studies. For the same reason, it is the first attempt to use such a detailed, highly disaggregated data to analyze the trading effects of $\mathrm{AD}$ protection. ${ }^{23}$

Extensive margin exploration, on the other hand, most closely related with Alvarez et al. (2009) in terms of the effect of previous exporting on the

23 Examples of papers (among others) using firm-level export data with the information on export destinations are: Eaton et al. (2005) and Buono (2009) for France, Manova (2009) for China, Alvarez et al. (2009) for Chile. 
probability of exporting a new product. Employing Chilean firm-level data which has the same features with ours (in terms of the details about exporting activities), their study documents that a firm's previous export experience increases the probability that the firm will export a previously exported product to a different market or a different product to a market where this firm already exported a product. Both Alvarez et al. and our study clearly points out that previous trading relationships which are important determinants of new exporting activities. With respect to trade policy implementations of extensive margin, our analysis also complements the set of papers (including, but not limited to Debeare and Mostashari 2010, Buono 2009, Buona and Lalanne 2010, KV 2009) examining the effect of protectionism (or liberalization) on the probability of observing new product varieties or new firms in export markets. For the first time in the literature, our investigation focuses on the question whether a country's imposition of an import restriction affects targeted firms' probability of exporting the particular product to alternative countries, rather than the duty imposer country itself. This provides additional implications to analyze the effect of trade policy on the variety of goods countries trade and on the number of exporting firms in different countries.

Our findings also provide additional insights to analyze the effect of trade deflection on the proliferation on $\mathrm{AD}$ actions around the world. For 
instance, Feinberg and Reynolds (2006, 2007) and Moore and Zanardi (2008) speculate that the spread of AD filings may partially be explained by trade deflection. ${ }^{24}$ As noted earlier, when exports are deflected to third countries, these third countries might also subsequently request more import protection in the form of $\mathrm{AD}$ duties. To capture this possible explanation, they use a variable which is equal to the number of global $\mathrm{AD}$ cases filed the previous year in the particular industry category. Although their estimates are significant, this variable does not capture the true effect of trade deflection due to the aggregation. It is not typical for a country to impose a restriction on a product because of a surge in imports in another product within the same industry. Second, this measure does not provide any clue about the destinations that exports should deflect to. For instance, a high number of AD duties imposed on steel products in North America against Mexico does not guarantee either trade deflection for all Mexican firms or trade deflection to all countries. As a matter of fact, it is less likely to observe a reaction from a country, which has a small import share of steel from North America, to a steel war in the region. Our study also raises additional concern to the WTO's China safeguard which allows members to deviate from MFN rule based on the threat of trade deflection. As more disaggregated firm-level data of exports become available, we believe that researchers should seriously focus on the trading relationships of firms in different countries when they

${ }^{24}$ We should note that the effect of trade deflection on the spread of $\mathrm{AD}$ filings is not the actual research question, whereas, it is a control variable in both papers. 
evaluate the threat of trade deflection and its effect on the rise of protectionist policies.

The remainder of the paper is organized as follows. The next section discusses the motivation of our empirical strategy, some preview discussion, the formal econometric methodology and alternative estimations we performed. In section 3 we describe the data, Section 4 documents the results. Finally, section 5 concludes.

\section{The Empirical Investigation}

\section{The classification of firm-product combinations}

Participating in export markets requires sunk start-up costs of establishing necessary networks, acquiring information about the official procedures and adapting products. This makes the current- period export supply dependent upon the previous exporting status, given the fact that firms are able to continue exporting without burdening the start-up costs if they already exported to a particular market before. ${ }^{25}$ Das et al. (2001), for instance, provide an estimation of such costs using structural estimates for Colombian firms and suggest that these costs are quite substantial; on average as high as 400,000 dollars. Most models of international trade on firm heterogeneity assume that these entry costs to export market are

\footnotetext{
25 See Dixit (1989) and, Baldwin and Krugman (1989), Bernard and Jensen (2001).
} 
constant and exogenous to the firm. ${ }^{26}$ More recently, utilizing Chilean firmlevel data Alvarez et al. (2009) uncovers sizeable heterogeneity across destinations in the nature of entry into different markets for firm-product combinations. Their study points out that these costs are indeed, market and product-market specific.

We also build our empirical strategy on these start-up costs of exporting. To do so, we classify the firms whose product is targeted by an $\mathrm{AD}$ duty on the basis of their previous trading relationships to alternative countries. Figure 1 demonstrates this classification in a three country setting. When country A imposes an AD duty on Brazilian exporters of good X, there are three types of firms at the time of duty imposition which are affected by this $\mathrm{AD}$ measure:

- Type 1 firm, which was exporting good X to country A and non-exporter in country B.

- Type 2 firm, which was exporting good X to both A and B.

- Type 3 firm, which was an exporter of good X in country A but exporter of another product in country B.

In order to deflect its trade to country B, type 1 firm, which did not export to country B before, has to incur the market and product-market specific start-up cost. However, type 3 firm does not have to incur the market specific start-up cost in a similar scenario, given the fact that it has already

${ }^{26}$ For example, Clerides et al. (1998) and Melitz (2003). 
served country B before. When it comes to the type 2 firm, which has an ongoing trading relationship for good $\mathrm{X}$ in both countries, there is no need to burden any start-up cost. Intuitively, deflecting trade to its trading partner for the type 2 firm is as easy as a couple of more phone calls compared to the type 1 firm which faces a burden of entering to a new country, contacting potential customers and establishing necessary distribution channels to sell its product. On the other hand, type 3 firm has a comparative advantage over type 1 firm in terms of market specific start-up costs such as learning the bureaucratic procedures to export to country B.

In the light of this three country setting, we classify the firm-product combinations for the observations where good $\mathrm{X}$ is hit with an $\mathrm{AD}$ measure in another country. To do so, we first create a dummy variable which takes on a value of 1 if a firm-product combination is targeted by an $\mathrm{AD}$ duty in a country besides the country of the unit observation. Following BC (2007), this variable is not zero in the period in which the investigation for an affirmative $\mathrm{AD}$ case is begun because of the fact that the targeted exporters begin to respond to tentative duty imposition shortly after the date filing is announced. Second, in order to identify the effect of previous trading relationships of the firms, we use three different dummies for the three types of past export status described above. ${ }^{27}$ More specifically, each $\mathrm{AD}$ duty imposed in an export market creates the three country case mentioned above

${ }^{27}$ We use three year definition to describe the firm's past export status. 
for Brazil, the duty imposer country and the destination country of the unit observation. Consequently, a firm-product combination might be classified as different types in different observations at a year depending on the destination. ${ }^{28}$ The effect of AD duty on type 2 firm-product group represents the intensive margin of trade deflection while, type 1 and type 3 represents the extensive margin. Further, we also undertake an alternative estimation for extensive margin and analyze whether the imposition of an $\mathrm{AD}$ duty in a country leads the targeted type 1 and type 3 firms to introduce their particular products in new markets.

In addition to the three types of firm-product combinations described above, there is also another type which is indirectly affected by the duty imposed in country $\mathrm{A}$ : those which were exporters of good $\mathrm{X}$ in $\mathrm{B}$, nonexporters in A. Although the duty imposed in country A does not directly affect them, part of the deflection in good X from country B to A can be explained by the depressed trade of the exporters in this category. Therefore, we also add these firm-product combinations to our classification as type 4.

Table 2.2 reports the summary statistics of our sample. When an $\mathrm{AD}$ duty imposed on a product, we have $41 \%$ of the firm-product combinations as type $2,27 \%$ as type 1 and $19 \%$ as type 3 . Our goal is to document the heterogeneity of trade deflection for these different types of previous trading relationships across destinations to analyze the potential export markets for

${ }^{28}$ We would also write "depending on the duty imposer". However, as shown in Table 1, there is no single year in which more than one country imposed $\mathrm{AD}$ duty to the same product. 
the firms to deflect trade when their products suffer an $\mathrm{AD}$ duty in the international market.

Before proceeding, a preview of this heterogeneity is shown in Figure 2.2. The vertical axis of the graph shows the mean value of the growth of exports for firm-product combinations in the sample and the solid horizontal line shows the sample average. In the horizontal axis, we denote our classifications when there is an $\mathrm{AD}$ duty imposed in an export market other than the particular destination. The increase in growth of exports due to an $\mathrm{AD}$ duty faced in an export market except the particular destination demonstrates the trade deflection. As shown in the figure, contrary to the slight difference for type 1, the average of export growth is much higher for type 2 and type 3 firm-product combinations when their product is hit with an $\mathrm{AD}$ duty. This suggests that firms tend to deflect a higher volume of trade to the countries where they already exported when their products suffer an $\mathrm{AD}$ duty in an export market. On the other hand, a higher average of export growth for type 2 firm-product combinations speaks to the influence of exporting the same product before on deflected trade. In our empirical section we evaluate the indicative heterogeneity shown in figure 2 and assess which type of trading relationship provides significant trade deflection when other factors are also taken into account. 


\section{Empirical Specification}

\section{Trade Deflection (Export Values)}

Consider first the variation in exports for a firm-product category across export destinations. The effect of an $\mathrm{AD}$ duty imposed by a country on the exports of the Brazilian firms to other countries can be interpreted as trade deflection. In order to quantify that effect, we start with the following reduced form equation:

$$
\begin{aligned}
& \ln \left(x_{f p i t}\right)=\beta_{1} \ln \left(x_{f p i t-1}\right)+\beta_{2}\left(A D_{f p h t} \times \text { Type } 1\right)+\beta_{3}\left(A D_{f p h t} \times \text { Type } 2\right)+ \\
& \beta_{4}\left(A D_{f p h t} \times \text { Type } 3\right)++\beta_{5}\left(A D_{f p h t} \times \text { Type } 4\right)+\beta_{6} \ln \left(W_{f t}\right)+\beta_{7} \ln \left(x_{f t-1}\right)+\varepsilon_{f p i t}
\end{aligned}
$$

where $f$ denotes a firm, $p$ denotes a six-digit HS product, $i$ denotes an export destination, $t$ denotes time in years. The variable $\left(x_{f p i t}\right)$ and $\left(x_{f t-1}\right)$ is the value of exports, $\left(A D_{\text {fpht }}\right)$ is a binary indicator, equal to 1 if the particular firm-product combination is hit with an $\mathrm{AD}$ duty in an export destination except country i; Type 1 , Type 2 and Type 3 and Type 4 are dummy variables to indicate the past exporting status to country $i$ at firm-product level as described above. Type 1 takes on a value of 1 if the firm in the unit observation is exporting the targeted product to country $h$ before the duty imposition, but non-exporter in country i. Type 2 is equal to 1 if the firm in the unit observation is exporting the targeted product to both countries $h$ and $i$ before the duty imposition; Type 3 is equal to 1 if the firm in the unit observation is exporting the targeted product to country $h$ before the duty 
imposition, non-exporter of that product but exporter of another product in country i. Finally, Type 4 is a binary indicator if the firm in the unit observation is non-exporter of the particular product in county $h$ but exporting it to country $i . B_{2}, B_{3}$ and $B_{4}$ denote the magnitude of trade deflection for each previous exporting relationship. Finally, $\left(W_{f t}\right)$ is a vector of firm characteristics.

We assume that $\varepsilon_{\text {fpit }}$ comprises two components, a permanent firmproduct-country component and a transitory component. So the error term satisfies:

$$
\varepsilon_{f p i t}=u_{f p i t}+\mu_{f p i}
$$

where $u_{f p i t} \sim \operatorname{iid}\left(0, \sigma_{\mathrm{U}}^{2}\right)$ and $\mu_{f p i} \sim \operatorname{iid}\left(0, \sigma_{\mu}^{2}\right)$ are independent of each other. Fixed effects (FE) estimator is one way of estimating equation (1) because it eliminates time invariant error component, $\mu_{f p i}$. However, the greatest econometric concern in $\mathrm{FE}$ estimation of equation (1) is that it results in biased and inconsistent estimates associated with the serial correlation of $\ln \left(x_{f p i t-1}\right)$ and $\ln \left(x_{f t-1}\right)$ with FE transformed residuals. In order to remedy this autocorrelation, we first difference equation (1) and estimate it using the two stage least squares/instrumental variables (IV) approach described in Anderson and Hsiao (1982) in which we instrument for $\Delta \ln \left(x_{f p i t-1}\right)$ and $\Delta \ln \left(x_{f t-1}\right)$ using the multiple lags of the levels of these variables. ${ }^{29}$

29 Note that direct estimation of the first difference of equation (1) by OLS also provides biased estimates because lagged difference of exports is correlated with the error term. 
Our IV first difference equation then becomes:

$$
\begin{aligned}
& \Delta \ln \left(\mathrm{x}_{\mathrm{fpit}}\right)=\beta_{1} \Delta \ln \left(\mathrm{x}_{\mathrm{ft}-1}\right)+B_{2} \Delta\left(\mathrm{AD}_{\mathrm{fpht}} * \mathrm{Type} 1\right)+\beta_{3} \Delta\left(\mathrm{AD}_{\mathrm{fpht}} * \text { Type } 2\right)+\beta_{4} \Delta\left(\mathrm{AD}_{\mathrm{fpht}}\right. \\
& * \text { Type } 3)+\beta_{5} \Delta\left(A D_{f p h t} \times \text { Type } 4\right)+\beta_{6} \Delta \ln \left(W_{f t}\right)+\beta_{7} \Delta \ln \left(x_{f t-1}\right)+\Delta \varepsilon_{f p i t}
\end{aligned}
$$

It should be emphasized that there are two potential problems with the IV estimator used in estimating equation (2); bias due to the measurement error and bias associated with the use of a weak instrument. If there is measurement error in $\ln \left(x_{f p i t}\right)$ and $\ln \left(x_{f t-1}\right)$, then the measurement error in the variables, $\Delta \ln \left(x_{f p i t-1}\right)$ and $\Delta \ln \left(x_{f t-1}\right)$, will be correlated with the measurement error in the instruments, $\ln \left(x_{f p i t-2}\right)$ and $\ln \left(x_{f t-2}\right)$.Therefore, we employ alternative instruments, $\ln \left(x_{f p i t-3}\right)$ and $\ln \left(x_{f t-3}\right)$, in consideration that their measurement error is not correlated with the measurement error in $\Delta \ln \left(x_{f p i t-1}\right)$ and $\Delta \ln \left(x_{f t-1}\right) .30$ In addition, to test the quality of the instruments, we estimate the first-stage model using our instruments. We find that our instruments are strong and conclude that IV approach is appropriate for our estimation. ${ }^{31} \mathrm{We}$ also document the estimates for both $\mathrm{FE}$ in levels and IV first difference estimation. ${ }^{32}$

${ }^{30}$ See BC (2007) for the same argument.

31 While we do not report the results of the instrument tests to save space, the first stage estimations are available from the author upon request.

32 An alternative strategy to estimate equation (2) would be the Generalized Method of Moments estimation described in Arellano and Bond (1991). However, when the country-year dummies are included for aggregate variation, this estimation becomes infeasible because of the large number of parameters to be estimated. 


\section{Extensive Margin of Trade Deflection}

We also investigate whether the imposition of an $\mathrm{AD}$ duty against Brazilian exported products in a particular export market affects the probability that targeted firms will start to export their duty imposed products to a new export destination. In other words, we analyze whether type 1 and type 3 firms, which are non-exporters of the targeted product in country $i$, becomes an exporter for that product as a result of an $\mathrm{AD}$ duty imposed in country $h$. We believe that firms whose products suffer AD duty in an export destination are more likely to start exporting their products to alternative markets where they previously exported given the fact that they have a comparative advantage in those markets in terms of country-specific start-up costs. To develop an understanding of the heterogeneity to the effect

of an $\mathrm{AD}$ duty on the firm-product combinations of different types of previous exporting activities, we start with the following binary choice model:

$$
\begin{aligned}
& P\left(y_{f p i t}=1\right)=\beta_{1} \ln \left(x_{f t-1}\right)+\beta_{2}\left(A D_{f p h t} \times T y p e 1\right)+\beta_{3}\left(A D_{f p h t} \times T y p e 3\right)+ \\
& \beta_{4} \ln \left(W_{f t}\right)+\vartheta_{f p i t}
\end{aligned}
$$

where the binary dependent variable $y_{f p i t}$ is equal to 1 if the firm $i$ starts to export product $p$ to country $i$ at time $t$. Once again, of particular interest are the $\mathrm{AD}$ policy interactions. $\beta_{2}$ can be interpreted as the change in the probability of observing a new product in country $i$ from the firms, which were non-exporters in country $i$, when an $\mathrm{AD}$ duty hits their exported product 
in country $h$. In a similar manner, $\beta_{3}$ shows the change in the same probability for the firms which were exporters of another product in country $i$.

The most important issue in estimation (4) is the influence of unobserved heterogeneity. There might be some permanent firm or product attributes; or managerial skills which are correlated with the decision to start exporting a particular product as a result of an $\mathrm{AD}$ duty faced in another destination. This will yield us to overestimate the effect of our policy interactions as these variations are not observed. There are different alternatives to estimate the binary choice model of starting to export a product with unobserved elements including maximum likelihood techniques such as probit or conditional logit, or linear probability model with random or fixed effects. For the reason that unobserved heterogeneity is correlated with our firm specific controls, random effect estimation is not appropriate for our specification. As a result, to model the unobserved heterogeneity as fixed, we choose to work with linear probability model. In addition, it is highly likely that unobserved characteristics in our model are serially correlated with $\ln \left(x_{f t-1}\right)$. Therefore, we follow a methodology similar to our earlier estimation to correct for autocorrelation and instrument for $\ln \left(x_{f t-1}\right)$ using its second lag. We advance in two steps. First, we undertake FE estimation of equation (4) in levels. Given the potential correlation of FE transformed residuals with the lagged export value, we also estimate our model using IV first differences 
in order to avoid the problem of inconsistent estimates found in the fixed effects model.

\section{Control Variables}

Exporters are found to be more productive than non-exporters. ${ }^{33}$ In line with this, a change in exporter firm's productivity over time might affect the total value of its shipments over time. Therefore, our policy interactions might capture the effect of a productivity shock at the firm level that would be correlated with the growth in exports or the decision to start exporting the product to a particular destination. The export data, SECEX, does not allow us to control for productivity because it contains no information on domestic sales. However, the lagged value of total exports proxies the productivity of the firms. ${ }^{34}$

On the other hand, we also control for the size of the firm which is measured by the total number of workers and the average wage bill paid by the firm within a year. It is believed that larger firms tend to be more productive and have higher expected profits from exporting. Moreover, as discussed in Bernard and Jensen (2004), size may control for several factors; larger firms might have lower average and marginal costs which cause an increase in the likelihood of exporting, also size is a proxy for past success by definition. Further, inclusion of the average wages paid by the exporting firms is motivated by the fact that higher wages paid by the firm is

${ }^{33}$ See Greenway and Kneller (2007) for a survey of this literature.

${ }^{34}$ Alvarez et al. (2009) 
associated with higher quality of output which positively affects exporting the goods into foreign markets. However, the limitation of using this variable is that its availability reduces our sample from roughly 800,000 to 49,000.

The growth in exports or the decision to start exporting a product to a particular country can also partially be explained by macroeconomic factors in the export market. For instance, trade openness, GDP growth and exchange rate appreciation in a potential export destination can work as an import demand shifter which would induce exporters to deflect their shipments to that destination. In this regard, we use country-year dummies to control for macroeconomic aggregates.

\section{Data}

Export data comes from the Brazilian customs office SECEX (Secretaria de Comércio Exterior) which gathers export reports by product code at the plant, month and NCM (Nomenclatura Comum do Mercosul) level. The $N C M$ codes are 8-digit numbers, of which the first six digits coincide with the first six digits in the Harmonized System. The destination information is mapped from Brazilian country codes into the international ISO system. Product codes at the 6-digit level in the Brazilian data, for which there exists no corresponding Harmonized System entries, are removed from the data. All export values in the SECEX data are reported in current U.S. dollars (USD), free on board (fob). We utilize observations on exporting plants, declared export values and export destinations for the years 1994 
through 2000. We aggregate monthly plant-level export information to years and firms. Export sales are deflated to their August-1994 equivalents using the monthly U.S. consumer price index (from Global Financial Data).

The employment and wage data of Brazilian firms are obtained from the collection of annual reports with individual information on workers and employees, which is called RAIS (Relacao Anual de Informacoes Sociais). Similar to our treatment of the export data, we aggregate the monthly worker-plant information to years and firms. We use the reported December wage, which is recorded in multiples of the "monthly minimum wage" that prevails at the time. The reported December wage in RAIS excludes the "thirteenth salary," which is a special December payment made in some sectors. Multiplying our reported December wage figures by twelve provides a good estimate of an annual wage. We calculate the wage value in Brazilian Real (BRL) and deflate all wages to August 1994. ${ }^{35}$

Finally, the data on $\mathrm{AD}$ is obtained from Global Antidumping Database. ${ }^{36}$ This database provides detailed product level information on the $\mathrm{AD}$ petitions such as the initiation date, the decision date, the targeted country, and the final decision of the $\mathrm{AD}$ authority as well as the HS codes of the products subject to filings. $\mathrm{AD}$ duties are not homogenous for countries and products; rather they can take the form of price undertaking, an ad

\footnotetext{
35 See Molina and Muendler (2009) and Hirakawa et al. (2010) for more information about SECEX and RAIS data.

36 http://econ.worldbank.org/ttbd/gad/
} 
valorem duty or a specific duty in different cases. Consequently, we use a dummy variable to identify the effect of $\mathrm{AD}$ given the different units in $\mathrm{AD}$ duties across cases and countries.

\section{Empirical Results}

The results from estimating equation (3) are shown in Table 2.3. In the first two columns, we do not include the $\mathrm{AD}$ policy interactions with previous exporting status, whereas we only use the $\mathrm{AD}$ duty dummy to compare the results with the specifications which include the interactions. As shown, our full sample has 548698 observations, however, adding the number of employees to regressions reduces the sample to roughly 460,000 and using the wage bill further reduces the sample to around 50,000. All specifications include country-year dummies to control for aggregate variation at the country level over time. In addition, based on the F-tests obtained in the first stage, we conclude that all of our instrumental variables are strong and our estimates are unbiased.

Consider first specifications (1) and (2). Looking at the insignificant estimates of the $\mathrm{AD}$ duty imposed on a $\mathrm{HS}$ six-digit product in specifications (1) and (2), we would conclude that $\mathrm{AD}$ duties does not cause trade deflection in our sample. However, interaction of the $\mathrm{AD}$ policy variable with the previous exporting status of the firms for the targeted product provides interesting outcomes in terms of trade deflection. Specification (3) through (5) 
documents the estimates for the AD duty interactions. Specification (4) controls for the size and specification (5) controls for both the size and the average wage bill. The estimates in these specifications provide strong evidence for the heterogeneity of the effect of $\mathrm{AD}$ duty on deflected trade for different types of previous exporting relationships. As shown, when there is an $\mathrm{AD}$ duty imposed on Brazilian exported products, there is no significant trade deflection to the countries where the firm was non-exporter before. However, the significant estimates of the coefficients on AD duty interactions with type 2 and type 3 suggests that firms whose product suffer an $\mathrm{AD}$ duty in a particular export destination, deflect their trade to alternative countries where they exported before. Although the coefficient on $\mathrm{AD}$ duty interaction with type 3 turns to be insignificant in specification (5), we do not observe whether it is due to the additional control we use or due to the decrease in our sample size. On the other hand, the significance of the variable $\left(A D_{f p h t} \times\right.$ Type2) is insensitive to the choice of control variables.

To better quantify the magnitude of trade deflection, we use the formula in Kennedy (1981) to convert the coefficient of the dummy variable to its true marginal effect. The result developed in his paper papers suggests that if the dependent variable is in logarithmic form, $\alpha$ is the estimated coefficient on a dummy variable and $V(\alpha)$ is the estimated variance of a then:

$$
p=100(\exp (\alpha-V(\alpha) / 2)-1)
$$


gives us an estimate of the percentage impact of the dummy variable on the variable being explained. The estimates in Table 3 demonstrates that imposition of a trade restriction in the form of an $\mathrm{AD}$ measure on a Brazilian HS product results in a \% 18 increase in the firms' exports of the targeted product to alternative countries where the firms previously exported that product. Trade deflection resulting from an $\mathrm{AD}$ duty is also remarkably higher to the countries where firms exported the targeted product compared to the countries where the firm did export another product. The coefficient estimates on $\left(A D_{\text {fpht }} \times\right.$ Type 3$)$ in Table 3 suggests that imposition of an $\mathrm{AD}$ duty leads to an $8 \%$ increase in the firms' exports of the targeted product to the countries where the firms were non-exporter for the duty imposed product, but exporter of another product.

In conclusion to table 2.3, the insignificant coefficient estimate of $\left(A D_{\text {fpht }} \times\right.$ Type 1$)$ points out that start-up costs of exporting plays a crucial role in determining the potential export market to deflect trade for the firms whose product suffer an $\mathrm{AD}$ duty in a particular destination. This is also closely related to the temporary feature of the $\mathrm{AD}$ duties. It would be reasonable for a targeted firm to deflect its trade to a country they never exported before as a result of a permanent change in a particular country's trade policy. However, the cost of the temporary adjustment in trade policy in the form of an $\mathrm{AD}$ duty in an export market does not seem enough to offset 
the start-up costs in another destination. In addition, the sizable increase in the growth of exports of the targeted products to the countries where the firms of those products have ongoing trading relationships is a further support to the start-up cost argument. Last but not least, the difference in coefficient estimates between $\left(A D_{f p h t} \times\right.$ Type 2$)$ and $\left(A D_{f p h t} \times\right.$ Type 3$)$ highlight the importance of product-market specific start-up costs in firms' decision to deflect trade to third countries when their product is hit with an $\mathrm{AD}$ duty in a particular destination. Further, the negative coefficient estimate of $\left(A D_{f p h t} \times\right.$ Type 4$)$ also speaks to the trade depressing effect of $\mathrm{AD}$ duty in the markets rather than the duty imposer. This shows that part of the deflection in trade is also due to the trade depression that some exporters (those whose products were not hit in country $h$ ) experienced in the alternative markets.

When it comes to control variables, all of them have predicted signs. The increase in the total export of firms in the previous year, the size which is measured by number of workers and the average wage bill is associated with a current export growth for a product category within firm. Since they are not of particular interest, we do not discuss them here in detail. ${ }^{37}$

In what follows, we also report the FE results in levels in Table 2.4 to provide a comparison on the IV first difference estimates we obtained,.

\footnotetext{
${ }^{37}$ We do the same for the remaining tables.
} 
Neither the sign nor the significance of the variables is changed. $\left(A D_{\text {fpht }} \times\right.$ Type 1) remains to be insignificant in all specifications. On the contrary, both $\left(A D_{\text {fpht }} \times\right.$ Type 2$)$ and $\left(A D_{\text {fpht }} \times\right.$ Type 3$)$ are significant despite their lower magnitude compared to the IV first difference estimation. This might indicate that controlling for firm-product-destination fixed effects absorbed much of the deflecting effect of the $\mathrm{AD}$ duties. $\mathrm{FE}$ estimation also reduced the coefficient estimates for the lagged export values and other firm characteristics.

Our final robustness check aims to address the concern that the deflecting effect of an $\mathrm{AD}$ duty might be particularly resulting from steel cases; given the fact that steel industry is the most frequently targeted industry as shown in Table 2.1. For that purpose, we add interactions of the $\mathrm{AD}$ policy variable with an indicator for whether the particular product is a steel or non-steel product. ${ }^{38}$ As documented in Table 2.5, including steel and non-steel interaction terms does not alter our results. Similarly, we find no evidence of trade deflection to the countries where firms did not export before both for steel and non-steel products. In contrast, there is a significant trade deflection to the countries where the firms had previous trading relationships for both product categories.

${ }^{38}$ Steel products are HS chapter 72 or 73. 
With respect to the magnitude of trade deflection, coefficient estimates in Table 2.5 shows that trade deflection to the countries where the firms have type 2 trading relationship is higher for steel products compared to non-steel ones. Imposition of an $\mathrm{AD}$ duty against Brazilian exported products yields a $19 \%$ increase in firms' exports of targeted steel product to the countries where the firms exported the particular product before. For non-steel products, the increase in exports to the same set of countries is $16 \%$. Further, when targeted by an $\mathrm{AD}$ duty in the export market, the increase in firms' exports to alternative markets where the firms served with another product is $5 \%$ for steel products and $10 \%$ for non-steel products. This higher effect of the interaction of non-steel dummy suggests that steel producers faced higher product specific start-up costs in export markets. This can also be attributed to the fact that steel exporters, which suffer an $\mathrm{AD}$ duty in a particular country, recognize the potential $\mathrm{AD}$ investigation they might face in another country given the fact that steel products accounts for the highest share in the total worldwide AD filings. Non-steel exporters, on the other hand, have less risk in terms of the same concern.

Having analyzed the trade deflection using export values, we report the results for the extensive margin of trade deflection in Tables 2.6 through 2.8. In these specifications the binary dependent variable takes on a value of 1 if the firm starts to export a particular product to a new export destination. 
The policy variable and its interactions assist us to identify whether the firms start to export a particular duty imposed product to an alternative destination. Table 2.6 documents the results of the linear probability model using IV first difference estimation. Once again, specifications (1) and (2) include the number of employees and the last specification includes the average bill. $\mathrm{F}$-test statistics obtained in the first stage implies that all of our instrumental variables are strong and our estimates are unbiased. Similar to the earlier results on trade deflection using export values, using the $\mathrm{AD}$ policy variable without interactions yields insignificant estimates as shown in specifications (1) and (2). In contrast, estimates in the specifications (3) through (5) provides a diversity for the effect of the imposed $\mathrm{AD}$ duties on the probability of starting to export the targeted product to a new country when the policy variable is interacted with type 1 and type 3 previous trading relationships.

First, insignificant estimates of $\mathrm{AD}$ policy interaction with type 1 indicates that $\mathrm{AD}$ duties imposed on a particular exported product does not affect the probability that firms start to export the targeted product to a new market where they were non-exporter of that product in the past. On the other hand, the coefficient estimates for $\left(A D_{f p h t} \times\right.$ Type 3$)$ suggest that the probability of observing a new firm-product combination in an export destination, where the firm already served with another product, is increased 
by $8-10 \%$ if an $\mathrm{AD}$ duty is imposed on the particular product in a different export destination.

To summarize, the effect of an $\mathrm{AD}$ duty imposed on a product by a country on the extensive margin of export flows to the third countries only appears in the form of existing exporters exporting the particular duty imposed product to the countries where they were serving via another product before. In contrast, we do not observe any effect on the probability that non-exporter of any product in a country starts to export a product which is hit with an $\mathrm{AD}$ duty in another country. This emphatically points out that suffering temporary $\mathrm{AD}$ duties in an export destination is not sufficient to trigger the firm to bear a whole burden of "market" and "product specific" start-up cost of exporting the targeted product to a different destination. However, it causes the targeted firms to burden a product-specific start-up cost for their targeted products in an export market they already served. Overall, Table 2.6 demonstrates that the role of past exporting status is clearly evident for the extensive margin of trade deflection to third countries resulting from an $\mathrm{AD}$ duty.

Table 2.7 shows the results of the FE estimates for the extensive margin of trade deflection. Similar to the earlier findings, the only difference of the FE estimation is that it generated slightly lower coefficients for the 
independent variables. However, neither the sign nor the significance of the coefficients changed.

One might be concerned that the estimates for the extensive margin of trade deflection are driven particularly by steel products. For this consideration, we include the steel and non-steel interactions in order to separate out the effect of $\mathrm{AD}$ duty. The results of this specification are reported in Table 2.8. As shown, while the interaction of the AD duty with the type 1 trading relationship is insignificant for both steel and non-steel products, the type 3 interaction is significant for both. Interestingly, the size of the increase in the probability to start exporting to the countries where the firms were exporters of another product is much higher for non-steel products. When hit with an $\mathrm{AD}$ duty, the probability that the firm will start exporting the targeted product to a destination they have already served increases by $4-7 \%$ for non-steel products; whereas, it increases by $1.5 \%-1.8 \%$ for steel products. This is also parallel to our earlier estimates of trade deflection using export values. Steel exporters seem to face a higher product specific start-up costs as a result of the political sensitivity of the steel industry in terms of import protection.

\section{Conclusion}

Trade deflection has become an important issue in the WTO and other Customs Unions' framework. From China specific safeguards to intra- 
regional trade protocols, there are many examples of policy debates regarding this issue. This paper represents the first attempt to utilize a rich three dimensional customs data of firms, products and export destinations to analyze the effect of past exporting relationships on trade deflection resulting from $\mathrm{AD}$ duties which targets Brazilian exported products during the 19942000 period. We document substantial heterogeneity of trade deflection to the countries depending on targeted firms' previous trading relationships. First, using the export values, we show that imposition of an $\mathrm{AD}$ duty on Brazilian products leads to an $18 \%$ increase in the firms' exports of the particular product to alternative countries where the firms previously exported that product and an $8 \%$ increase in the firms' exports of the particular product to the countries where the firms exported another product. To the contrary, we find no significant effect of $\mathrm{AD}$ duties on the exports of the firms' particular product to alternative countries the firm did not export before. This clearly demonstrates that firms are more willing to deflect trade to their ongoing trading partners instead of starting to export to a different destination in order to avoid paying the market specific start-up costs. In addition, the higher magnitude of deflected trade to the countries the firm exported the same product compared to the countries the firm exported another product, points out the role of product-market specific start-up costs of exporting for the decision to deflect shipments to alternative destinations. Further, exploring the extensive margin of trade deflection, we demonstrate that 
imposition of an $\mathrm{AD}$ duty against Brazil increases the probability that Brazilian firms will introduce the particular product to a new market they previously served. When targeted by an $\mathrm{AD}$ duty in an export market, a firm's probability to start exporting the duty imposed product in a different destination increases by $8-10 \%$ if the firm already exported to that destination. However, our estimates show no such evidence for the countries to which the firm did not export before. We also show that estimated trade deflection varies for steel and non-steel products, which is the result of the political sensitivity of the steel products in terms of $\mathrm{AD}$ investigations.

Our paper also paves the way for a more detailed exploration of trade deflection using the firm level data in order to better understand the trading effects of $\mathrm{AD}$ policy not only for the duty imposer and the targeted country but also for the third countries which are not named in the investigation. In addition, we also point out a new perspective to examine the relationship between trade deflection and the spread of worldwide $\mathrm{AD}$ filings. We believe that researchers and policy makers should focus more on exporting firms' past trading relationships when evaluating the threat of trade deflection to the rules and bindings of World trading system.

Another related question regarding our paper is that whether the targeted firms switch exported products in the duty imposer country when they deflect their trade to different destinations or whether the imposition of 
an $\mathrm{AD}$ duty in a country affects the firms' exports of another product, rather than the targeted one, because of trade deflection. While our focus in this paper is the effect of past trading relationships on trade deflection, analyzing the trading effects of $\mathrm{AD}$ in terms of these related topics is an attractive avenue for future research. 
Table 2.1. Antidumping duties imposed on Brazil

\begin{tabular}{|c|c|c|c|}
\hline Case & Imposing country & Product & Year \\
\hline 1 & USA & Stainless Steel Wire Rod & 1994 \\
\hline 2 & USA & Ferrosilicon & 1994 \\
\hline 3 & USA & Silicomanganese & 1994 \\
\hline 4 & USA & Stainless Steel Bar & 1994 \\
\hline 5 & Australia & A4 Cut Ream Copy Paper & 1994 \\
\hline 6 & Australia & Fibreglass Gun Rovings & 1994 \\
\hline 7 & Canada & Corrosion Resistant Steel Sheet & 1994 \\
\hline 8 & European Union & Pig Iron (Hematite) & 1994 \\
\hline 9 & India & Bisphenol-A & 1994 \\
\hline 10 & Mexico & Specialty Steel Products & 1994 \\
\hline 11 & European Union & Ferro-Silico Manganese & 1995 \\
\hline 12 & Mexico & Hot-Rolled Steel & 1995 \\
\hline 13 & Mexico & Steel Sheets & 1995 \\
\hline 14 & Mexico & Cold-Rolled Steel & 1995 \\
\hline 15 & Mexico & Steel Plates In Rolls & 1995 \\
\hline 16 & Mexico & Corrugated Iron Sheets & 1995 \\
\hline 17 & Mexico & Butyl Rubber & 1995 \\
\hline 18 & USA & Pressure Pipe & 1995 \\
\hline 19 & Mexico & Steel Connectors & 1996 \\
\hline 20 & Peru & Calcium Carbide & 1997 \\
\hline 21 & Argentina & Chain Saws & 1997 \\
\hline 22 & Argentina & Ceramic Magnets & 1997 \\
\hline 23 & Argentina & Fuses & 1997 \\
\hline 24 & South Africa & Suspension PVC & 1997 \\
\hline 25 & Argentina & Gas Carafe & 1998 \\
\hline 26 & Argentina & Fiber Optic Cables & 1998 \\
\hline 27 & European Union & Monosodium Glutamate & 1998 \\
\hline 28 & South Africa & Uncoated wood-free paper & 1998 \\
\hline 29 & Argentina & Chains & 1999 \\
\hline 30 & Argentina & Abrasives & 1999 \\
\hline 31 & Argentina & Flat Laminated Products & 1999 \\
\hline 32 & South Africa & Cut paper (A4) & 1999 \\
\hline 33 & Argentina & Eviscerated Chicken & 2000 \\
\hline 34 & Argentina & Javelins & 2000 \\
\hline 35 & Argentina & Denim & 2000 \\
\hline 36 & Argentina & Steel Sheets & 2000 \\
\hline 37 & Canada & Hot-Rolled Carbon Steel Plate & 2000 \\
\hline 38 & Canada & Stainless Steel Round Bar & 2000 \\
\hline 39 & European Union & Malleable Cast Iron Pipe Fittings & 2000 \\
\hline
\end{tabular}


Figure 2.1: Exporting status of the firms before the duty imposition
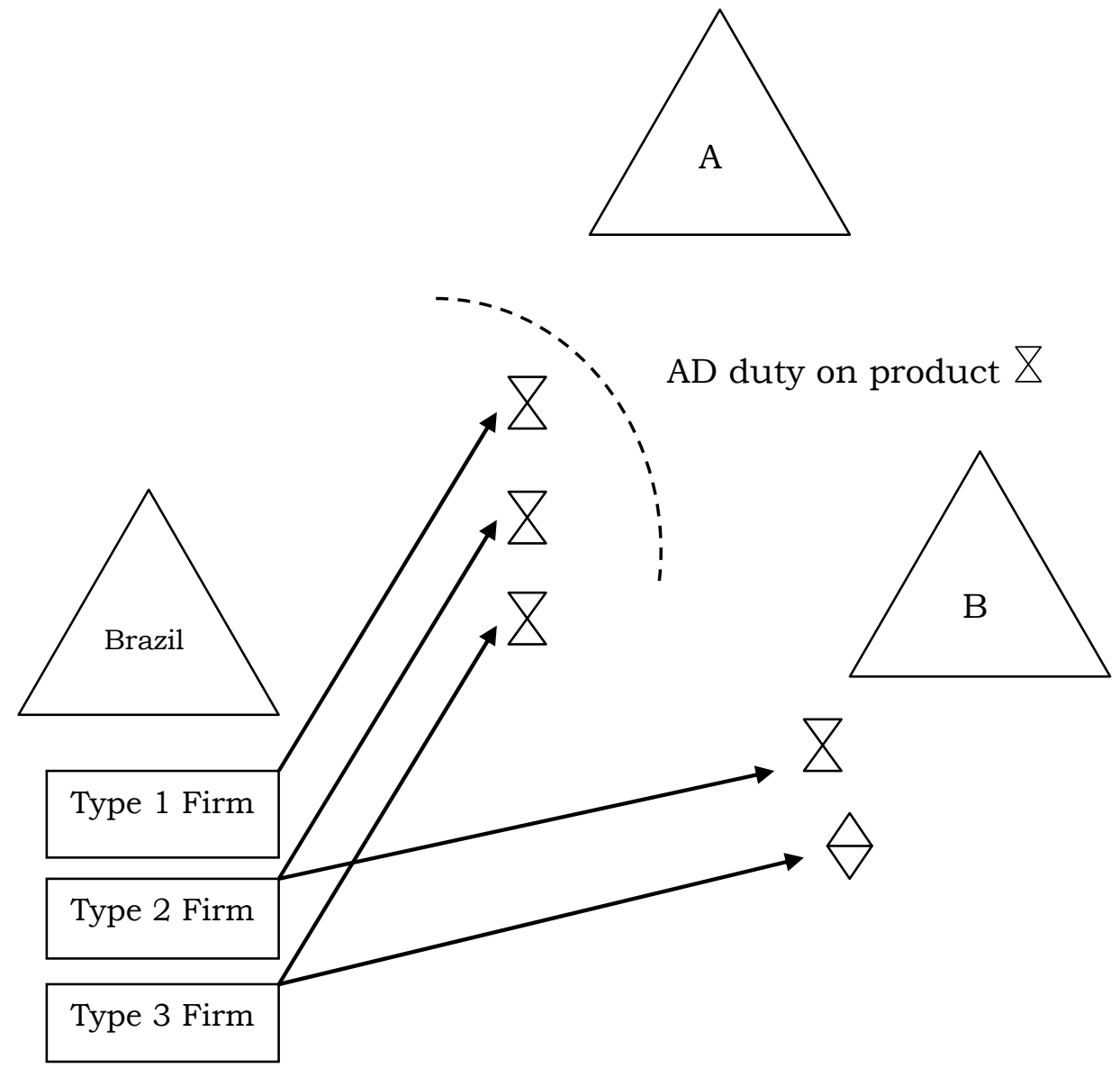

$\longrightarrow \quad$ Trade flows for the products. 
Figure 2.2: Mean value of the growth of $\ln (\exp )_{f p i}$

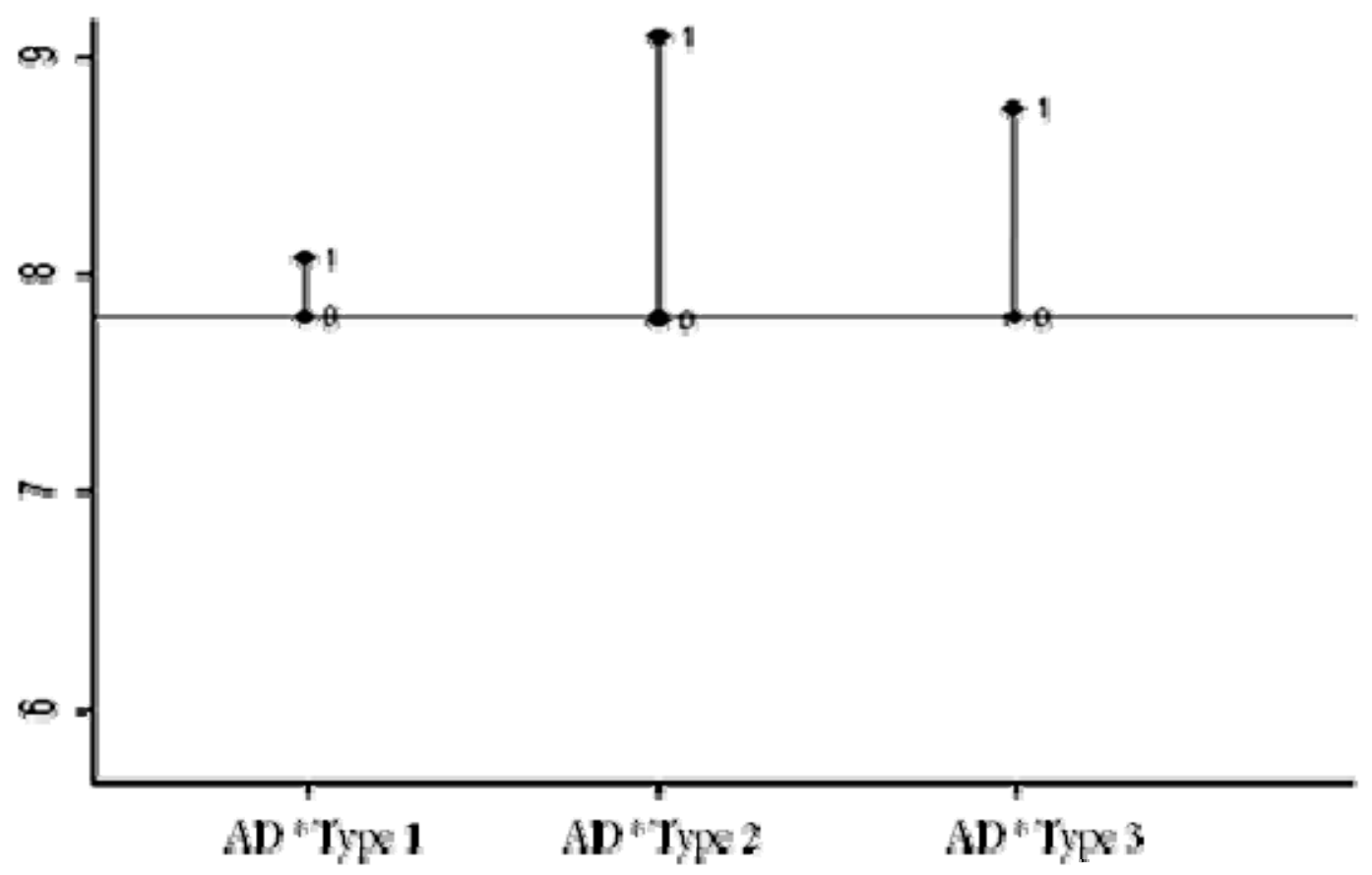

Source: Global Antidumping Database, SECEX and RAIS Notes: Mean value of the growth of $\ln (\exp )_{f p i}$ is in the horizontal axis. Subscript $f$ is a firm, $p$ is a 6-digit HS product, $i$ is an export market. 
Table 2.2. SUMMARY STATISTICS

\begin{tabular}{lllc}
\hline Variable & Mean & Standard deviation & $\mathrm{N}$ \\
\hline $\begin{array}{l}\text { Dependent variables } \\
\Delta \ln \left(\exp _{f p i t}\right)\end{array}$ & 3.466 & 1.399 & 548698 \\
New Product & 0.370 & 0.042 & 548698 \\
Explanatory variables & & & \\
ADdutyt ${ }^{*}$ type1 & 0.197 & 0.301 & 548698 \\
ADdutyt $*$ type 2 & 0.080 & 0.167 & 548698 \\
ADdutyt ${ }^{*}$ type3 & 0.053 & 0.082 & 548698 \\
ADdutyt ${ }^{*}$ type4 & 0.037 & 0.066 & 548698 \\
$\Delta \ln \left(\exp _{f t}\right)$ & 0.025 & 0.543 & 548698 \\
$\Delta \ln \left(\right.$ employment $_{f t}$ & 3.467 & 4.284 & 548698 \\
$\Delta\left(\right.$ wagebill $_{f t}{ }^{*}$ & -0.0576 & 0.514 & 461638 \\
\hline \hline
\end{tabular}

Source: Global Antidumping Database, SECEX and RAIS.

Notes: Subscript $f$ is a firm, $p$ is a 6-digit HS product, $i$ is an export market, $t$ is a year. * millions of BRL. 
Table 2.3. IV First Difference Estimation

Dependent variable: $\Delta \ln \left(\exp _{\text {fpit }}\right)$

\begin{tabular}{|c|c|c|c|c|c|}
\hline & 1 & 2 & 3 & 4 & 5 \\
\hline$A D$ duty & $\begin{array}{l}-1.119 \\
(0.35)\end{array}$ & $\begin{array}{l}-1.087 \\
(0.57)\end{array}$ & & & \\
\hline$A D$ duty*type 1 & & & $\begin{array}{l}-1.509 \\
(0.87)\end{array}$ & $\begin{array}{l}-1.484 \\
(0.67)\end{array}$ & $\begin{array}{l}-1.023 \\
(0.45)\end{array}$ \\
\hline$A D$ duty*type 2 & & & $\begin{array}{l}0.172 \\
(20.35) * * *\end{array}$ & $\begin{array}{l}0.171 \\
(18.70) * * *\end{array}$ & $\begin{array}{l}0.134 \\
(4.80) * * * *\end{array}$ \\
\hline$A D$ duty*type 3 & & & $\begin{array}{l}0.072 \\
(2.99)^{* * *}\end{array}$ & $\begin{array}{l}0.075 \\
(2.87)^{* *}\end{array}$ & $\begin{array}{l}0.115 \\
(0.56)\end{array}$ \\
\hline$A D$ duty*type 4 & & & $\begin{array}{l}-0.119 \\
(2.89)^{* *}\end{array}$ & $\begin{array}{l}-0.091 \\
(2.85)^{* * *}\end{array}$ & $\begin{array}{l}-0.115 \\
(2.65)^{* *}\end{array}$ \\
\hline $\ln \left(\exp _{f p i t-1}\right)$ & $\begin{array}{l}0.203 \\
(36.52)^{* * * *}\end{array}$ & $\begin{array}{l}0.288 \\
(36.54) * * * *\end{array}$ & $\begin{array}{l}0.203 \\
(37.45)^{* * * *}\end{array}$ & $\begin{array}{l}0.283 \\
(36.33)^{* * * *}\end{array}$ & $\begin{array}{l}0.187 \\
(23.36)^{* * * *}\end{array}$ \\
\hline $\ln \left(\exp _{f t-1}\right)$ & $\begin{array}{l}0.075 \\
(12.25) * * *\end{array}$ & $\begin{array}{l}0.074 \\
(10.23) * * *\end{array}$ & $\begin{array}{l}0.089 \\
(24.54) * * *\end{array}$ & $\begin{array}{l}0.084 \\
(26.65) * * *\end{array}$ & $\begin{array}{l}0.069 \\
(13.65) * * *\end{array}$ \\
\hline $\ln \left(e m p_{f t}\right)$ & & $\begin{array}{l}0.125 \\
(17.95)^{* * * *}\end{array}$ & & $\begin{array}{l}0.110 \\
(13.98)^{* * * *}\end{array}$ & $\begin{array}{l}0.213 \\
(6.59)^{* * * *}\end{array}$ \\
\hline Avg.wage & & & & & $\begin{array}{l}0.000 \\
(1.99)^{* * *}\end{array}$ \\
\hline $\begin{array}{l}\text { Country - year } \\
\text { Observations }\end{array}$ & $\begin{array}{l}\text { Yes } \\
548698\end{array}$ & $\begin{array}{l}\text { Yes } \\
461638\end{array}$ & $\begin{array}{l}\text { Yes } \\
548698\end{array}$ & $\begin{array}{l}\text { Yes } \\
491638\end{array}$ & $\begin{array}{l}\text { Yes } \\
49176\end{array}$ \\
\hline
\end{tabular}

Notes: Tables 2.3-2.8: Subscript $f$ is a firm, $p$ is a 6 -digit HS product, $i$ is an export market, $t$ is a year. Absolute values of $\mathrm{t}$ statistics are in parentheses. ). ${ }^{* * *},{ }^{* *},{ }^{*}$ show the level of significance in $99 \%, 95 \%$ and $90 \%$ respectively. All specifications include a constant term which is suppressed. 
Table 2.4. Fixed Effects Estimation (Levels)

\begin{tabular}{|c|c|c|c|c|c|}
\hline & 1 & 2 & 3 & 4 & 5 \\
\hline$A D$ duty & $\begin{array}{l}-0.041 \\
(0.36)\end{array}$ & $\begin{array}{l}-0.032 \\
(0.29)\end{array}$ & & & \\
\hline AD duty*type 1 & & & $\begin{array}{l}-0.104 \\
(0.89)\end{array}$ & $\begin{array}{l}-0.184 \\
(0.72)\end{array}$ & $\begin{array}{l}-0.107 \\
(0.65)\end{array}$ \\
\hline$A D$ duty*type 2 & & & $\begin{array}{l}0.127 \\
(16.71) * * *\end{array}$ & $\begin{array}{l}0.127 \\
(16.15)^{* * *}\end{array}$ & $\begin{array}{l}0.129 \\
(4.11) * *\end{array}$ \\
\hline$A D$ duty*type 3 & & & $\begin{array}{l}0.037 \\
(7.32) * * *\end{array}$ & $\begin{array}{l}0.026 \\
(6.72)^{* * *}\end{array}$ & $\begin{array}{l}0.024 \\
(0.92)\end{array}$ \\
\hline$A D$ duty*type 4 & & & $\begin{array}{l}-0.016 \\
(0.29)\end{array}$ & $\begin{array}{l}-0.015 \\
(0.76)\end{array}$ & $\begin{array}{l}-0.014 \\
(0.73)\end{array}$ \\
\hline $\ln \left(\exp _{f p i t-1}\right)$ & $\begin{array}{l}0.038 \\
(87.62) * * *\end{array}$ & $\begin{array}{l}0.041 \\
(86.54) * * *\end{array}$ & $\begin{array}{l}0.044 \\
(86.16) * * *\end{array}$ & $\begin{array}{l}0.045 \\
(85.03) * * *\end{array}$ & $\begin{array}{l}0.032 \\
(67.34) *\end{array}$ \\
\hline $\ln \left(\exp _{f t-1}\right)$ & $\begin{array}{l}0.026 \\
(18.44) * * *\end{array}$ & $\begin{array}{l}0.024 \\
(17.69) * * *\end{array}$ & $\begin{array}{l}0.032 \\
(10.65) * * *\end{array}$ & $\begin{array}{l}0.042 \\
(9.65) * * *\end{array}$ & $\begin{array}{l}0.019 \\
(7.86)^{* * *}\end{array}$ \\
\hline $\ln \left(e m p_{f t}\right)$ & & $\begin{array}{l}0.092 \\
(5.49)^{* * *}\end{array}$ & & $\begin{array}{l}0.084 \\
(8.45) * * *\end{array}$ & $\begin{array}{l}0.146 \\
(7.65) * *\end{array}$ \\
\hline Avg.wage & & & & & $\begin{array}{l}0.000 \\
(4.37) * *\end{array}$ \\
\hline Country - year & Yes & Yes & Yes & Yes & Yes \\
\hline Observations & 548698 & 461638 & 548698 & 491638 & 49176 \\
\hline
\end{tabular}


Table 2.5. IV First Difference Estimation

(Steel vs. Non-steel Products)

Dependent variable: $\Delta \ln \left(\exp _{f p i t}\right)$

\begin{tabular}{|c|c|c|c|}
\hline & 1 & 2 & 3 \\
\hline AD duty*type1*non-steel & $\begin{array}{l}-1.551 \\
(0.65)\end{array}$ & $\begin{array}{l}-1.691 \\
(0.76)\end{array}$ & $\begin{array}{l}-1.443 \\
(0.52)\end{array}$ \\
\hline AD duty*type $2 *$ non-steel & $\begin{array}{l}0.159 \\
(21.55) * * *\end{array}$ & $\begin{array}{l}0.145 \\
(20.84) * * *\end{array}$ & $\begin{array}{l}0.127 \\
(4.18)^{* * *}\end{array}$ \\
\hline AD duty*type $3^{*}$ non-steel & $\begin{array}{l}0.091 \\
(16.22) * * *\end{array}$ & $\begin{array}{l}0.087 \\
(11.76) * * *\end{array}$ & $\begin{array}{l}0.083 \\
(0.75)\end{array}$ \\
\hline AD duty*type $4^{*}$ non-steel & $\begin{array}{l}-0.093 \\
(1.97)^{*}\end{array}$ & $\begin{array}{l}-0.091 \\
(1.98) *\end{array}$ & $\begin{array}{l}-0.087 \\
(0.65)\end{array}$ \\
\hline AD duty*type $1{ }^{*}$ steel & $\begin{array}{l}-2.091 \\
(0.36)\end{array}$ & $\begin{array}{l}-2.010 \\
(0.40)\end{array}$ & $\begin{array}{l}-1.879 \\
(0.25)\end{array}$ \\
\hline AD duty*type $2^{*}$ steel & $\begin{array}{l}0.185 \\
(18.85) * * *\end{array}$ & $\begin{array}{l}0.188 \\
(18.21) * * *\end{array}$ & $\begin{array}{l}0.167 \\
(2.17) * *\end{array}$ \\
\hline AD duty*type ${ }^{*}$ steel & $\begin{array}{l}0.049 \\
(16.22) * * *\end{array}$ & $\begin{array}{l}0.046 \\
(2.44)^{* *}\end{array}$ & $\begin{array}{l}0.043 \\
(0.55)\end{array}$ \\
\hline$A D$ duty*type $4^{*}$ non-steel & $\begin{array}{l}-0.112 \\
(2.01)^{* *}\end{array}$ & $\begin{array}{l}-0.124 \\
(1.99) *\end{array}$ & $\begin{array}{l}-0.093 \\
(0.47)\end{array}$ \\
\hline $\ln \left(\exp _{\text {fpit }-1}\right)$ & $\begin{array}{l}0.220 \\
(27.70) * * *\end{array}$ & $\begin{array}{l}0.209 \\
(26.00)^{* * *}\end{array}$ & $\begin{array}{l}0.226 \\
(4.47) * * *\end{array}$ \\
\hline $\ln \left(\exp _{f t-1}\right)$ & $\begin{array}{l}0.085 \\
(21.05) * * *\end{array}$ & $\begin{array}{l}0.080 \\
(20.17) * * *\end{array}$ & $\begin{array}{l}0.096 \\
(3.26) * * *\end{array}$ \\
\hline $\ln (e m p f t)$ & & $\begin{array}{l}0.127 \\
(25.79) * * *\end{array}$ & $\begin{array}{l}0.231 \\
(7.59) * * *\end{array}$ \\
\hline Avg.wage & & & $\begin{array}{l}0.001 \\
(4.66) * * *\end{array}$ \\
\hline Country - year dummies & Yes & Yes & Yes \\
\hline Observations & 548698 & 461638 & 49176 \\
\hline$R^{2}$ & 0.14 & 0.14 & 0.19 \\
\hline
\end{tabular}


Table 2.6. IV First Differences Estimation of Extensive Margin

\begin{tabular}{llllll}
\hline & 1 & 2 & 3 & 4 & 5 \\
\hline AD duty & 0.001 & 0.001 & & & \\
& $(0.34)$ & $(0.32)$ & & & \\
AD duty*type1 & & & -0.031 & -0.009 & -0.006 \\
& & & $(0.57)$ & $(0.76)$ & $(0.98)$ \\
AD duty*type3 & & & 0.105 & 0.082 & 0.098 \\
& & & $(2.23)^{* *}$ & $(2.17)^{* *}$ & $(1.98)^{* *}$ \\
$\ln ($ expft-1) & 0.021 & 0.023 & 0.022 & 0.021 & 0.026 \\
& $(3.16)^{* * *}$ & $(3.27)^{* * *}$ & $(6.15)^{* * *}$ & $(7.27)^{* * *}$ & $(2.88)^{* * *}$ \\
$\ln ($ empft $)$ & & 0.001 & & 0.001 & 0.001 \\
& & $(2.20)^{* *}$ & & $(2.01)^{* *}$ & $(2.22)^{* *}$ \\
Avg.wage & & & & & 0.001 \\
& & & & & $(12.79)^{* * *}$ \\
Country - year dummies & Yes & Yes & Yes & Yes & Yes \\
Observations & 893405 & 548698 & 893405 & 548698 & 49176 \\
$R^{2}$ & 0.29 & 0.27 & 0.24 & 0.28 & 0.30 \\
\hline
\end{tabular}

Note: Binary dependent variable $=1$ if firm $f$ starts to export a new product $p$ to country $c$ 


\section{Table 2.7. Fixed Effects Estimation of Extensive Margin}

Binary dependent variable $=1$ if firm $f$ starts to export a new product $p$ to country c

\begin{tabular}{|c|c|c|c|c|c|}
\hline & 1 & 2 & 3 & 4 & 5 \\
\hline$\overline{A D d u t y}$ & $\begin{array}{l}0.001 \\
(0.34)\end{array}$ & $\begin{array}{l}0.001 \\
(0.59)\end{array}$ & & & \\
\hline$A D$ duty*type 1 & & & $\begin{array}{l}-0.078 \\
(0.22)\end{array}$ & $\begin{array}{l}-0.068 \\
(0.39)\end{array}$ & $\begin{array}{l}-0.043 \\
(0.54)\end{array}$ \\
\hline$A D$ duty*type 3 & & & $\begin{array}{l}0.081 \\
(199.50)^{* *}\end{array}$ & $\begin{array}{l}0.068 \\
(204.63)^{* *}\end{array}$ & $\begin{array}{l}0.074 \\
(14.44)^{* * *}\end{array}$ \\
\hline $\ln \left(\exp _{f t-1}\right)$ & $\begin{array}{l}0.012 \\
(278.07)^{* * *}\end{array}$ & $\begin{array}{l}0.012 \\
(281.40)^{* * *}\end{array}$ & $\begin{array}{l}0.012 \\
(288.07)^{* *}\end{array}$ & $\begin{array}{l}0.012 \\
(234.29)^{* *}\end{array}$ & $\begin{array}{l}0.022 \\
(617.38)^{*}\end{array}$ \\
\hline $\ln \left(e m p_{f t}\right)$ & & $\begin{array}{l}0.000 \\
(2.05)^{* *}\end{array}$ & & $\begin{array}{l}\stackrel{*}{0.000} \\
(0.88)\end{array}$ & $\begin{array}{l}0.001 \\
(3.17)^{* * *}\end{array}$ \\
\hline Avg.wage & & & & & $\begin{array}{l}0.000 \\
(14.77)^{* * *}\end{array}$ \\
\hline Country - year & Yes & Yes & Yes & Yes & Yes \\
\hline Observations & 893405 & 548698 & 893405 & 548698 & 49176 \\
\hline$R^{2}$ & 0.29 & 0.30 & 0.34 & 0.38 & 0.35 \\
\hline
\end{tabular}


Table 2.8. IV First Differences Estimation of Extensive Margin

\begin{tabular}{|c|c|c|c|}
\hline & 1 & 2 & 3 \\
\hline AD duty*type 1 *nonsteel & $\begin{array}{l}-1.005 \\
(0.32)\end{array}$ & $\begin{array}{l}-1.005 \\
(0.37)\end{array}$ & $\begin{array}{l}-0.907 \\
(0.26)\end{array}$ \\
\hline AD duty*type ${ }^{*}$ nonsteel & $\begin{array}{l}0.071 \\
(230.45)^{* * *}\end{array}$ & $\begin{array}{l}0.068 \\
(238.34)^{* * *}\end{array}$ & $\begin{array}{l}0.027 \\
(15.82)^{* * *}\end{array}$ \\
\hline AD duty*type 1 *steel & $\begin{array}{l}-0.070 \\
(0.49)\end{array}$ & $\begin{array}{l}-0.089 \\
(0.36)\end{array}$ & $\begin{array}{l}-0.065 \\
(0.47)\end{array}$ \\
\hline AD duty*type ${ }^{*}$ steel & $\begin{array}{l}0.018 \\
(8.28)^{* * *}\end{array}$ & $\begin{array}{l}0.015 \\
(8.99)^{* * *}\end{array}$ & $\begin{array}{l}0.016 \\
(1.96)^{* *}\end{array}$ \\
\hline $\ln \left(\exp _{f t-1}\right)$ & $\begin{array}{l}0.068 \\
(682.60)^{* * *}\end{array}$ & $\begin{array}{l}0.067 \\
(651.87)^{* * *}\end{array}$ & $\begin{array}{l}0.077 \\
(262.50)^{* * *}\end{array}$ \\
\hline $\ln \left(e m p_{f t}\right)$ & & $\begin{array}{l}0.003 \\
(8.74)^{* * *}\end{array}$ & $\begin{array}{l}0.012 \\
(5.63)^{* * *}\end{array}$ \\
\hline Avg.wage & & & $\begin{array}{l}0.001 \\
(5.63)^{* * *}\end{array}$ \\
\hline Country - year dummies & Yes & Yes & Yes \\
\hline Observations & 893405 & 548698 & 49176 \\
\hline$R^{2}$ & 0.29 & 0.28 & 0.30 \\
\hline
\end{tabular}

Binary dependent variable $=1$ if firm $f$ starts to export a new product $p$ to country $c$ 


\section{CHAPTER 3}

\section{RETALIATION THREATS AND THE QUALITY OF EXPORTS}

\section{Introduction}

The last two decades witnessed rising administrative protection via antidumping $(\mathrm{AD})$ measures. When countries negotiate lower tariffs in trade agreements, domestic industries that desire protection against imports can still use several methods to gain temporary protection. The most popular of these methods is to claim that the trade partner is dumping, or selling below the "fair value". This claim is often made and often generates temporary protection, even if it is not true [Konings and Vandenbusche (2008) and Aggarwal (2007)]. Antidumping is a very effective loophole that has been exploited by developed as well as developing countries. ${ }^{39}$ According to the records of Global Antidumping Database, roughly 4,500 AD petitions have been filed in the last 20 years by more than 40 countries.

Much of the existing studies propose a number of political and strategic considerations to explain the proliferation of $\mathrm{AD}$, albeit an ideal case aims to hinder unfair competition in the international market. One of these proposed explanations is that countries tend to retaliate against the countries which previously named them in their $\mathrm{AD}$ investigations. [Miranda et al. (1998), Prusa and Skeath (2002), Francois and Niels (2004), Feinberg

\footnotetext{
${ }^{39}$ See Blonigen and Prusa (2003) for an extensive survey.
} 
and Reynolds (2006)] These studies suggest that this tit-for-tat strategy for $\mathrm{AD}$ actions has created an "AD club" which consists of countries which have implemented AD law and actively utilizing it. Blonigen and Bown (2003), on the other hand, provide another perspective to this debate. They propose that the worldwide spread of $\mathrm{AD}$ in fact may dampen $\mathrm{AD}$ activity given the fact that countries become able to retaliate when they start enforcing this law. Concentrating on the US AD activity, they show that the risk of a potential reaction from the target country decreases the probability of observing $\mathrm{AD}$ petition from the US industries as well as the likelihood of an affirmative $\mathrm{AD}$ outcome from the US AD agency. Although whether the retaliation enables or dampens the spread of worldwide $\mathrm{AD}$ activity is widely examined, nothing is known about the exporter firms' response to a threat of $\mathrm{AD}$ retaliation. To our knowledge, this is the first paper to address this issue.

This paper empirically analyzes the effect of potential $\mathrm{AD}$ measures (from retaliation) on the quality of products that are exported to the markets which may file $\mathrm{AD}$. Our idea is that when products are vertically differentiated and price of the goods represents the level of quality, exporting firms will increase the quality of their exports to the countries whose importers are subject to an $\mathrm{AD}$ investigation because of the risk of being retaliated for that $\mathrm{AD}$ investigation. Using rich three dimensional customs data of Brazilian firms which allows us to see the quality heterogeneity 
across export destinations within the same firm-product groups; we find that potential $\mathrm{AD}$ reaction from a particular export destination significantly increases the quality of exported products to the same destination.

Several studies stressed that a major concern regarding the $\mathrm{AD}$ investigations is that they do not take into consideration the quality differentials when evaluating the price discrimination in "like products". For instance, Veugelers and Vandenbussche (1999) and Vandenbussche and Wauthy (2001) note the objections on AD duty impositions of European Commission from the exporters whose products were in low quality standards and have poor brand image compared to their European competitors. These studies point out that dumping reflects a "cost advantage" instead of "unfair trade". However, since no quality adjustments are made, exporters of the lowquality goods, which charge lower price in order to sell their products, are experiencing more risk of being targeted by an $\mathrm{AD}$ claim. ${ }^{40}$ In line with this argument, when an $\mathrm{AD}$ petition is filed by domestic industries and the exporters' flexibility to discriminate prices between the home and the target country is restrained because of the threat of retaliation, an expected response from the exporting firms is to increase the quality of their shipments, which is sold for higher prices, in order to avoid that threat. This hypothesis is strongly supported in our empirical analysis by matching the

\footnotetext{
${ }^{40}$ See also Nielsen and Rutkowski (2005) and Hansen and Nielsen (2009) for a similar argument.
} 
detailed product-level information on $\mathrm{AD}$ cases with highly disaggregated export data over the years 1997-2000.

The main findings in this paper can be summarized as follows. Potential $\mathrm{AD}$ claims, resulting from an $\mathrm{AD}$ investigation in Brazil, increases the quality of firms' exports within the named industry to the target countries by $11 \%$. Second, we also addressed the concern that a potential AD filing in an export destination is more important for the firms for which the named industries' products in the target country constitute a significant share of their total exports. Our estimates based on this interaction also show that one standard deviation increase from the mean in the export share of the firms' products which are exposed to retaliation is associated with a $6 \%$ increase in the quality of the exported products to the same country. Third, we show that this effect is $4 \%$ higher for the exporters serving the developed countries. This can be attributed to the fact that due to the negligence of quality differences in $\mathrm{AD}$ investigations, firms exporting to the developed countries are more responsive to the retaliation risk because of the higher quality production and higher prices charged for the like products in these countries. Last but not least, we also show that the increase in the quality of exported varieties as a result of retaliation threats is $3 \%$ higher to the heavy $\mathrm{AD}$ user countries. This last finding shows that exporters consider the high potential of retaliation in those countries associated with their past $\mathrm{AD}$ 
activity and increase the quality of their exports in their markets more than they do in the ones with average $\mathrm{AD}$ activity.

Our paper most closely complements the recent work of Konings and Vandenbussche (2009) which examines the effect of France's own imposed AD duties on the export sales of the protected firms. Employing firm-level customs data of French exporters, they show that foreign sales of the exporters decrease dramatically for the protected firms. In presenting the arguments on the decrease in the exports of the protected firms, they also point out that this might be the consequence of the limitations of price setting in the international market stemming from the $\mathrm{AD}$ protection in the home market. Similar to theirs, our analysis also focuses on the effect of own AD activity on the exports market than the domestic market. However, there are two key points that differs our work. First, they use a difference in difference approach to see the effect of $\mathrm{AD}$ on the exports of the protected firms compared to a control group of unprotected ones. In contrast, our focus is not the effect of the $\mathrm{AD}$ protection in the home market, but the threat of retaliation because of the ongoing $\mathrm{AD}$ investigation, regardless of its tentative outcome. Prusa (2001) shows that exporters react to a tentative AD duty imposition right after the $\mathrm{AD}$ investigation is filed and $\mathrm{AD}$ filings reduce the imports of the named countries even if they are not affirmative. From this point of view, investigations themselves trigger the retaliatory incentives of 
the target country. ${ }^{41}$ Second, our analysis is based on the trading effects of the own $\mathrm{AD}$ activity in a particular export destination, namely the target country of the investigation at home, rather than the entire international market. In this regard, the three dimensional information on firms, products and export destinations in our data perfectly fits into our research question.

Although conceptually different, this study is also related to the group of papers which analyze the effect of trade policy on the quality of imported varieties. One of the more well-known works on quality upgrading is from Feenstra (1988) who presented evidence that US imposed import quota restraints resulted in substantial upgrading in Japanese car imports. His findings suggest that Japanese firms substituted toward high quality given the restriction on their quantity of shipments. Das and Donnenfeld (1987), Krishna (1987), Herguera et al. (2000) and Toshimitsu (2005) also theoretically supported the argument that the average quality increases with the trade restriction that exporters face. For the first time in the literature, our focus is the quality upgrading resulting from a potential trade restriction rather than the imposed one. In this respect, $\mathrm{AD}$ duties offer a useful starting point given the incremental strategic motivations behind their world-wide implementations.

\footnotetext{
${ }^{41}$ Studies on retaliation and $\mathrm{AD}$ also use the filing behaviors as the dependent variable.
} 
It is also worth noting that, besides its rich firm-level export data, Brazil is a suitable country for our analysis in terms of its AD activity as well. Having implemented the AD law in 1987, Brazil ranks in the top ten out of all World Trade Organization (WTO) members in the category of number of AD petitions filed after the WTO's inception in 1995. Brazil filed $71 \mathrm{AD}$ cases over the sample of our data. In addition, as documented in Table 3.1, Brazil targeted its major trading partners which are also very active $\mathrm{AD}$ users. Brazil also seems to be a member of the "AD club" given the fact that almost all of these countries also targeted Brazil over the same time period in several cases. Therefore, considering the threat of $\mathrm{AD}$ retaliation is an important point for the exporters not only because of the dramatic impact of $\mathrm{AD}$ duties on trade flows but also because of the target countries' past $\mathrm{AD}$ activities against Brazil. In table 3.2, we also document the $\mathrm{AD}$ petitions of Brazil by three-digit ISIC industries. In line with the world-wide $\mathrm{AD}$ activities, chemicals and iron-steel industries dominate the filings which are followed by food, textile and rubber products industries. ${ }^{42}$

The remainder of the paper is organized as follows. The second section describes the data, in section three we present the empirical methodology and and results, we conclude with section four.

\footnotetext{
${ }^{42}$ Although chemicals industry (ISIC 351) represents the $38 \%$ of total AD filings, the firmproduct combinations of this industry constitute only $2 \%$ of our sample.
} 


\section{Data}

We employ the detailed export data of Brazilian customs office SECEX (Secretaria de Comércio Exterior) which gathers export reports by product code at the plant, month and NCM (Nomenclatura Comum do Mercosul) level. The $N C M$ codes are eight-digit numbers, of which the first six digits coincide with the first six digits in the Harmonized System. The destination information is mapped from Brazilian country codes into the international ISO system. The product codes at the six-digit level in the Brazilian data, for which there exist no corresponding Harmonized System entries, are removed from the data. All export values in the SECEX data are reported in current U.S. dollars (USD), free on board (fob). We use observations on exporting plants, declared export values, export destinations and export quantities and we aggregate monthly plant-level export information to years and firms. We only focus on the manufactured products. The main variable of interest in our analysis is the unit price of the exported good $p$, shipped by firm $f$ to destination $d$ which is;

$$
u_{f p d}=\frac{\text { Export value }_{f p d}}{\text { Quantity }_{f p d}}
$$

Following the common practice in the international trade literature, we use this variable to proxy the quality of exported products. Our sample covers between years 1997 and 2000 given the fact that export quantities are 
available only for this time period. Besides, we removed all observations if the export value is zero and there is no information on quantity of shipments.

The employment data of Brazilian firms is obtained from RAIS (Relacao Anual de Informacoes Sociais) which is the collection of annual reports with individual information on workers and employees. Similarly, we aggregate the monthly worker-plant information to years and firms.

Finally, the data on AD activity is obtained from Global Antidumping Database. ${ }^{43}$ This database provides detailed case level information on the $\mathrm{AD}$ initiations and outcomes such as the date of the initiation and the decision, the target country, the final decision of the $\mathrm{AD}$ authority as well as the HS codes of the products subject to filings. To match the six-digit HS products with their three-digit ISIC codes, we used the concordances in the Trade Production and Protection Database of the World Bank.

\section{Empirical Methodology and Results}

\section{Baseline Specification}

As discussed, we are primarily interested in the variation of Brazilian firms' export unit values within products across the export destinations. To quantify the effect of the threat of retaliation on the quality of exports shipped, we begin with estimating the following baseline equation:

$$
\log \left(u_{f p d t}\right)=\gamma_{0}+\gamma_{1}(\text { Threat })_{k d, t-1}+\varepsilon_{f p d t}
$$

${ }^{43}$ http://econ.worldbank.org/ttbd/gad/ 
where $f$ denotes the firm, $p$ denotes the six-digit HS product, $d$ denotes the export destination and $k$ denotes the three-digit ISIC industry. As noted earlier, the variable $u_{f p d}$ denotes the unit prices of the exported products, which proxies the quality of shipments. (Threat) $k d, t-1$ is a binary indicator which takes on a value of "1" if Brazil filed an $\mathrm{AD}$ investigation against country $d$ within the three-digit ISIC industry category $k$ in the previous year $(t-1)$. Since countries which have not implemented AD law have no capacity to retaliate, this variable is zero for such countries. In addition, as shown in Table 3.1, a number of countries from European Union (EU) were defendant in Brazil's AD investigations the time period of our sample. Since AD is an EU-wide policy, we threat EU as a single country in our analysis. ${ }^{44}$

\section{Other Considerations}

We include firm-product-destination fixed effects in our specifications to control for the firm level unobservables, such as managerial ability; to account for the heterogeneity in the units of measurement in quantities, which is used to create the quality index; and to control for the time invariant country specific factors, such as distance.

In addition, as stated in Verhoogen (2008), Kugler and Verhoogen (2008) and Hallak and Sivadasan (2008), larger and more productive firms

\footnotetext{
${ }^{44}$ Our results are insensitive to treating each EU country as a different market as well as removing EU countries from the sample.
} 
pay higher wages, employ better inputs which results in higher quality in exports. Although we do not have information on domestic sales, we use the "number of workers" obtained from the linked employment data to proxy the size of the firm. ${ }^{45}$

A recent literature (including, but not limited to Hallak 2006, Kneller and Yu 2008, Harrigan and Deng 2008, Manova and Zhang 2010, Bastos and Silva 2010), on the other hand, has documented that the unit value of shipments increases with distance, size and the income of the destination country. Therefore, part of the variation in unit export values can be explained by these country specific covariates. In this regard, we use countryyear dummies to control for all time variant destination market aggregates, such as GDP and exchange rate. Further, Manova and Zhang (2010) demonstrated a positive relationship between the revenue exporters earn and the prices they charge in the export market. For this consideration, we also include the total revenue that the firm earns in the export destination. ${ }^{46}$

Another concern in estimating (2) is that export revenues and quantities might be measured with error. Following the convention, we removed the outliers as firm-product-destination combinations with export values below the $1^{\text {st }}$ percentile or above the $99^{\text {th }}$ percentile of the distribution

\footnotetext{
${ }^{45}$ The linked employment data also reports the wage bill paid by the firm. However, the availability of this variable is so limited in our sample, which does not allow us to utilize.

${ }^{46}$ While we do not report here, using total revenue that the firm earns from the same product in the destination as an alternative measure does not alter our findings.
} 
to dampen the bias associated with the measurement error. The extensive fixed effects our specifications also attenuates concerns with measurement error to a certain degree. 47

\section{Results}

After removing the observations with individual exporting activities, zero values for quantities and export values, we end up with roughly 450,000 observations. All regression results are derived from a panel-data fixed effect estimation in which the panel is a firm-product-destination triplet. All specifications include country-year dummies to control for the aggregate variation in the export market. Table 3.4 contains the main results from estimating equation (2). In column (1), we report our estimates without controls. We include our two controls, the revenue measure and the firm size, in specifications (2) and (3) respectively. The variable "log(revenue) fdt" denotes the total revenue that the firm $f$ earns in the market $d$ and the variable "log(employment) $)_{f t}$ " denotes the number of workers that the firm $f$ employs. The availability of the former determines the sample size in the last two specifications.

As documented in table 3.4, our variable of interest, retaliation threat, is significant in all of the specifications. This suggests that exporting firms react to potential $\mathrm{AD}$ measures in an export destination by upgrading the

\footnotetext{
${ }^{47}$ See Manova and Zhang (2010) for the same argument.
} 
quality of their shipments. In terms of economic magnitudes, when Brazil files and $\mathrm{AD}$ investigation against the importers of an industry from a particular country, Brazilian exporters increase the quality of the exported products within the same industry to the named countries by $11 \%$ because of the threat of retaliation. ${ }^{48}$ In addition, complementing the earlier studies, the coefficient estimates of the size and the revenue variable suggests that firms that are larger and that are generating more revenues in a destination export higher quality of product varieties to the same destination.

\section{Who fears more from retaliation?}

\section{The role of export share}

Thus far we have shown that retaliation threats affect the quality of the firms' exported products to the countries subject to $\mathrm{AD}$ investigation in the home country. In this section, we want to address the argument that potential $\mathrm{AD}$ claims in an export destination is not equally important for all firms. Exporting firms, for which the products of the particular industry in the target country constitutes a significant share of their exports, would be more responsive to the risk of retaliation. Therefore, in order to have less exposure to retaliation, an expected response from these firms is to increase the quality of exported products more than those of firms having smaller

\footnotetext{
${ }^{48}$ We use the formula in Kennedy (1981) to convert the coefficient of the dummy variable to its true marginal effect.
} 
export share for the same product group in the target country. In order to test this hypothesis, we first create a variable to measure the export share which is calculated as the ratio of firm f's export sales of products within the particular three-digit ISIC industry $k$ in country $d$ to the firm $f$ s total export sales. Second, we include an interaction term between the dummy variable which denotes the risk of retaliation and the measure of export share in our specifications.

As shown in the first column of table 5, we obtain a significant estimate for the interaction term. The retaliation threat variable also remains significant. This suggests that the effect of the retaliation threats on the quality of firms' exports is significantly increasing in the share of the exports of the named industries' products shipped to the target country in the firms' total exports. To gauge the economic significance, consider a one standard deviation increase from the mean in the export share of the firms' products which are exposed to retaliation. Such an increase would be associated with a $6 \%$ increase in the quality of the exported product to the same country.

\section{Exporters serving the richer countries}

Do the firms exporting to the developed countries experience more exposure to retaliation? The abstract of Hansen and Nielsen (2009) notes: 
The GATT/WTO rules allow for antidumping measures if domestic producers, exposed to price discrimination, also demonstrate injury where price-undercutting is an important indicator of the latter. The paper shows that the procedure for calculating injury is flawed due to negligence of quality differences in the calculation of the margin priceundercutting. This gives countries with high quality producers an option to practice protectionism. This asymmetry between countries in ability to implement antidumping measures predominantly favors the developed countries which are specialized in producing high quality products.

This critical view on $\mathrm{AD}$ investigations has important implications in terms of our research question. Firms which export to developed countries are experiencing tougher competition in their markets where firms produce higher quality of products. Since the quality differentials are often ignored in the calculation of "fair value", the risk of being subject to an $\mathrm{AD}$ investigation is higher in these countries when exporters of the lower quality products discriminate prices in order to survive. Following this line of argument, when retaliation threat is the focus, exporters which serve the countries richer than Brazil will burden more risk of retaliation compared to their counterparts which serve the less developed world. Consequently, we expect a higher 
quality upgrading for the firms serving developed markets resulting from retaliation threats.

To examine this issue, we include an interaction term between our policy variable and a binary indicator "Rich" which takes on a value of 1 if the destination country is classified as a "developed country" in the World Bank's classification. The coefficient estimates for this specification is reported in the second column of Table 5. The interaction term is statistically significant along with the actual variable of interest. This clearly points out a higher reaction to a threat of retaliation from the exporters which serve the developed countries. In terms of the magnitude of the effect, there is a $15 \%$ increase in the quality of the products to rich countries because of the threat of retaliation within the industry which is subject to filing in Brazil.

\section{Exporters serving the heavy $A D$ users}

Although AD policy is spread worldwide, some countries AD activity is significantly higher than others. For instance, Japan, which filed the first AD investigation in 1982, only has $6 \mathrm{AD}$ petitions until 2000. On the other hand, India, one of the latest $\mathrm{AD}$ law implementer, has become the heaviest $\mathrm{AD}$ user in the world. Obviously, the likelihood of being retaliated is higher for the firms serving the heavy $\mathrm{AD}$ users. Thus, firms might be more responsive to the threat of retaliation in these countries given this higher risk. 
In order to investigate whether the destination countries' $\mathrm{AD}$ activity affects the quality choice of the exporting firms' products which are exposed to retaliation, we interact our variable of interest with another dummy variable "Heavy" which takes on a value of 1 if the destination country's total AD filings is higher than the average of the total world $\mathrm{AD}$ filings in the previous five years. The regression estimates obtained using this variable is reported in the last column of Table 5. Similar to the earlier estimates, both the retaliation threat variable and the interaction term is statistically significant. This suggests that the increase in the quality of the exporting firms' products which are susceptible to retaliation is higher in the export destinations which are heavy $\mathrm{AD}$ users. In terms of economic significance, there is a $13 \%$ increase in the quality of firms' exported products to the heavy $\mathrm{AD}$ users when these countries are defendant in Brazil's $\mathrm{AD}$ investigation within the same industry.

\section{Conclusion}

Antidumping has become the most frequently implemented non-tariff trade barrier over the years. Especially after WTO's inception in 1995 and the dramatic tariff cuts countries have experienced, its importance has been increased for the firms which seek alternative instruments of protection. Since AD duties are so large as opposed to MFN (Most favored nations) tariffs, they have dramatic impact on both dumped imported varieties and 
domestic production. Although these effects are widely investigated in the literature, as noted in Konings and Vandenbussche (2009), there is not much work done on their effects on domestic exports. In this study, we examined one channel that affects the exporters as a result of the $\mathrm{AD}$ investigations filed by the domestic industry, which is the risk of retaliation.

We find strong support for the hypothesis that exporting firms will increase the quality of their shipments to the countries named in the $\mathrm{AD}$ investigations because of the risk of retaliation. Using Brazil's customs data of firm-level exports which has detailed information on products and export destinations, we demonstrated a significant quality upgrading after the $\mathrm{AD}$ filings in the home market from the exporting firms serving the target countries with products within the named industry. Potential AD claims, resulting from an $\mathrm{AD}$ investigation in Brazil, increases the quality of firms' exports for the named industries' products to the target countries by $11 \%$. This effect is significantly increasing in the share of the exports of the named industries' products in the target country in the firms' total exports. One standard deviation increase from the mean in the export share of the firms' products which are exposed to retaliation is associated with a $6 \%$ increase in the quality of the exported product to the same country. Further, we also show that this effect is $4 \%$ higher for the exporters serving the developed countries and $2 \%$ higher for the exporters serving the heavy $\mathrm{AD}$ users. 
Table 3.1. Brazil's antidumping filings by industries

(1996-1999)

\begin{tabular}{|c|c|c|}
\hline & Three digit ISIC industry & $\begin{array}{l}\text { Number of } \\
\text { Cases }\end{array}$ \\
\hline 311 & Food products & 5 \\
\hline 313 & Beverages & 0 \\
\hline 314 & Tobacco & 0 \\
\hline 321 & Textiles & 3 \\
\hline 322 & Wearing Apparel except footwear & 0 \\
\hline 323 & Leather products & 0 \\
\hline 324 & Footwear except rubber or plastic & 0 \\
\hline 331 & Wood products except furniture & 0 \\
\hline 332 & Furniture except metal & 0 \\
\hline 341 & Paper and products & 0 \\
\hline 342 & Printing and publishing & 0 \\
\hline 351 & Industrial chemicals & 27 \\
\hline 352 & Other chemicals & 3 \\
\hline 353 & Petroleum refineries & 0 \\
\hline 354 & Miscellaneous petroleum and coal products & 0 \\
\hline 355 & Rubber products & 6 \\
\hline 356 & Plastic products & 0 \\
\hline 361 & Pottery, china, earthenware & 0 \\
\hline 362 & Glass and products & 1 \\
\hline 369 & Other non-metallic min. products & 4 \\
\hline 371 & Iron and steel & 15 \\
\hline 372 & Non-ferrous metals & 0 \\
\hline 381 & Fabricated metal products & 2 \\
\hline 382 & Machinery except electrical & 1 \\
\hline 383 & Machinery electric & 0 \\
\hline 384 & Transport equipment & 0 \\
\hline 385 & Professional and scientific equipment & 2 \\
\hline 390 & Other manufactured products & 1 \\
\hline
\end{tabular}


Table 3.2. Defendant countries in Brazil's antidumping investigations

(1996-1999)

\begin{tabular}{|c|c|}
\hline Country & $\begin{array}{l}\text { Number } \\
\text { of cases }\end{array}$ \\
\hline USA & 10 \\
\hline China & 9 \\
\hline Germany & 4 \\
\hline South Africa & 4 \\
\hline France & 3 \\
\hline India & 3 \\
\hline Mexico & 3 \\
\hline Spain & 3 \\
\hline Romania & 3 \\
\hline United Kingdom & 3 \\
\hline Chile & 2 \\
\hline Japan & 2 \\
\hline Kazakhstan & 2 \\
\hline Russia & 2 \\
\hline Venezuela & 2 \\
\hline Argentina & 1 \\
\hline Australia & 1 \\
\hline Bangladesh & 1 \\
\hline Bulgaria & 1 \\
\hline Cuba & 1 \\
\hline Denmark & 1 \\
\hline Hong Kong & 1 \\
\hline Italy & 1 \\
\hline Netherlands & 1 \\
\hline New Zealand & 1 \\
\hline Poland & 1 \\
\hline Thailand & 1 \\
\hline Taiwan & 1 \\
\hline Ukraine & 1 \\
\hline Uruguay & 1 \\
\hline
\end{tabular}




\section{Table 3.3. Summary Statistics}

\begin{tabular}{|c|c|c|c|c|c|}
\hline & $\mathrm{N}$ & Mean & $\begin{array}{l}\text { Standard } \\
\text { deviation }\end{array}$ & Min & Max \\
\hline $\log \left(u_{f p d t}\right)$ & 443253 & 3.588 & 2.788 & -14.957 & 16.008 \\
\hline $\log (\text { revenue })_{f d t}$ & 443253 & 11.989 & 2.431 & 4.615 & 21.112 \\
\hline$(\text { Threat })_{k d, t-1}$ & 443253 & 0.111 & 0.193 & 0 & 1 \\
\hline $\log (\text { employment })_{f t}$ & 343252 & 3.985 & 1.719 & 0.693 & 12.105 \\
\hline Export Share & 443253 & 0.270 & 0.373 & $1.76 \mathrm{E}-07$ & 1 \\
\hline
\end{tabular}

Notes: $p$ denotes six-digit HS product, $k$ denotes three-digit ISIC industry, $f$ denotes firm, $d$ denotes destination and $t$ denotes time in years.

Sources: SECEX, RAIS and Global Antidumping Database. 
Table 3.4. Estimation Results

(The effect of retaliation threats on the quality of exported products)

\begin{tabular}{|c|c|c|c|c|}
\hline \multicolumn{5}{|c|}{ Dependent variable: $\log \left(u_{f p d t}\right)$} \\
\hline & 1 & 2 & 3 & 4 \\
\hline \multirow[t]{2}{*}{$(\text { Threat })_{k d, t-1}$} & 0.113 & 0.115 & 0.110 & 0.118 \\
\hline & $(0.053)^{* *}$ & $(0.053)^{* *}$ & $(0.061)^{* *}$ & $(0.061)^{* *}$ \\
\hline \multirow[t]{2}{*}{$\log (\text { revenue })_{f d t}$} & & 0.043 & 0.042 & 0.042 \\
\hline & & $(0.002)^{* *}$ & $(0.002)^{* *}$ & $(0.003)^{* *}$ \\
\hline \multirow[t]{2}{*}{$\log ($ employment) $f t$} & & & 0.010 & 0.009 \\
\hline & & & $(0.002)^{* * *}$ & $(0.002)^{* * *}$ \\
\hline Country-year dummies & Yes & Yes & Yes & Yes \\
\hline Firm-product-destination fixed effects & Yes & Yes & Yes & Yes \\
\hline$R^{2}$ & 0.17 & 0.24 & 0.28 & 0.28 \\
\hline Observations & 443253 & 443253 & 343252 & 343252 \\
\hline
\end{tabular}

Notes: $p$ denotes six-digit HS product, $k$ denotes three-digit ISIC industry, $f$ denotes firm, $d$ denotes destination and $t$ denotes time in years. Standard errors are in the parentheses (clustered by firm-product combinations). ${ }^{* * *},{ }^{* *}$, ${ }^{*}$ show the level of significance in 99\%, 95\% and 90\% respectively. All specifications include a constant term which is suppressed. 
Table 3.5. Who fears more from retaliation?

(The effect of retaliation threats on the quality of exported products)

Dependent variable: $\log \left(u_{f p d t}\right)$

\begin{tabular}{|c|c|c|c|}
\hline & $\begin{array}{l}\text { The role of } \\
\text { export share }\end{array}$ & $\begin{array}{l}\text { The role of richer } \\
\text { countries }\end{array}$ & $\begin{array}{l}\text { The role of heavy } \\
\mathrm{AD} \text { users }\end{array}$ \\
\hline \multirow[t]{2}{*}{$(\text { Threat })_{k d, t-1}$} & 0.077 & 0.081 & 0.078 \\
\hline & $(0.033)^{* *}$ & $(0.042)^{* *}$ & $(0.038)^{* *}$ \\
\hline \multirow{2}{*}{$\begin{array}{l}(\text { Threat })_{k d, t-1} \\
\text { share }\end{array}$} & & & \\
\hline & $(0.054) *$ & & \\
\hline \multirow[t]{2}{*}{$(\text { Threat })_{k d, t-1} x$ Rich } & & 0.069 & \\
\hline & & $(0.017)^{* * *}$ & \\
\hline \multirow[t]{2}{*}{$(\text { Threat })_{k d, t-1} x$ Heavy user } & & & 0.054 \\
\hline & & & $(0.019) *$ \\
\hline \multirow[t]{2}{*}{$\log (\text { revenue })_{f d t}$} & 0.045 & 0.120 & 0.121 \\
\hline & $(0.003)^{* * *}$ & $(0.004)^{* * *}$ & $(0.004)^{* * *}$ \\
\hline \multirow[t]{2}{*}{$\log ($ employment) $f t$} & 0.010 & 0.009 & 0.009 \\
\hline & $(0.002)^{* * *}$ & $(0.002)^{* * *}$ & $(0.002)^{* * *}$ \\
\hline Country-year dummies & Yes & Yes & Yes \\
\hline $\begin{array}{l}\text { Firm-product-destination fixed } \\
\text { effects }\end{array}$ & Yes & Yes & Yes \\
\hline$R^{2}$ & 0.28 & 0.26 & 0.28 \\
\hline Observations & 343252 & 343252 & 343252 \\
\hline \multicolumn{4}{|c|}{$\begin{array}{l}\text { firm, } d \text { denotes destination and } t \text { denotes time in years. Standard errors are in the } \\
\text { parentheses (clustered by firm-product combinations). }{ }^{* * *},{ }^{* *},{ }^{*} \text { show the level of } \\
\text { significance in } 99 \%, 95 \% \text { and } 90 \% \text { respectively. All specifications include a constant } \\
\text { term which is suppressed. }\end{array}$} \\
\hline
\end{tabular}




\section{LIST OF REFERENCES}

Aggarwal, Aradhna. 2007. The Antidumping Agreement and Developing Countries, Oxford University Press

Alesina, A. 1987. Macroeconomic policy in a two-party system as a repeated game, Quarterly Journal of Economics 102-651-678.

Álvarez, R., López, R. A., 2005. Exporting and Performance: Evidence from Chilean Plants. Canadian Journal of Economics 38(4), 1384-1400.

Alvarez, R., Faruq, H., Lopez R., 2009. Is Previous Export Experience Important for New Exports?. mimeo.

Anderson, T.W., Hsiao, C., 1982. Formulation and estimation of dynamic models using panel data. Journal of Econometrics 18, 47-82.

Bagwell, K., Staiger, R.W., 1997. Multilateral tariff cooperation during the formation of free trade areas. International Economic Review 38, 291-319.

Bagwell, K., Staiger, R.W., 1999. An economic theory of GATT. American Economic Review 89, 215-248.

Bagwell, K., Staiger, R.W., 2004. Multilateral trade negotiations, bilateral opportunism and the rules of GATT/WTO. Journal of International Economics 63, 1-29.

Baldwin, R. E., Krugman, P., 1989. Persistent Trade Effects of Large Exchange Rate Changes, Quarterly Journal of Economics (104), 635-654.

Bastos, P. and J. Silva. 2010. The Quality of a Firm's Exports: Where You Export to Matters. Journal of International Economics 82 (2):99-11

Belderbos, R., 1997. Antidumping and tariff Jumping: Japanese firms' DFI in the European union and the United States. Review of World Economics (Weltwirtschaftliches Archiv) 133(3), 419-457

Bernard, A., Jensen, B., 2004. Why Some Firms Export. Review of Economics and Statistics (86), 561-569.

Bown, C., Crowley, M., 2007. Trade Deflection and Trade Depression. Journal of International Economics 72(1), 176-201.

Bown, C., Crowley, M., 2010. China's Export Growth and the China Safeguard: Threats to the World Trading System?. Canadian Journal of Economics43(4), forthcoming 
Beck, Thorsten, G. Clarke, A. Groff, P. Keefer, and P. Walsh. 2001. New tools in comparative political economy: The Database of political institutions, World Bank Economic Review 15: 165-76.

Blonigen, Bruce A. and Chad P. Bown. 2003. Antidumping and Retaliation Threats, Journal of International Economics, 60(2): 249-73.

Blonigen, B.A. 2006. Working the System: Firm Learning and the Antidumping Process, European Journal of Political Economy, 22: 715-731.

Blonigen, B. and T.J. Prusa. 2003. Antidumping. In Handbook of International Trade, edited by E.K. Choi and J. Harrigan. Oxford, U.K. and Cambridge, MA: Blackwell Publishers.

Bown, Chad P. 2006. The World Trade Organization and Antidumping in Developing Countries, World Bank Policy Research Working Paper No. 4014

Bown, Chad P. 2007. The WTO and Antidumping in Developing Countries", Economics and Politics, 20(2): 255-88

Bown, Chad P. and Patricia Tovar. 2008. Trade Liberalization, Antidumping, and Safeguards: Evidence from India's Tariff Reform, mimeo.

Bown, Chad P. 2009. Global Antidumping Database, [Version 5.0, July], available at www.brandeis.edu/ cbown/global_ad/

Buono, I., 2009. Firm heterogeneity and comparative advantage: the response of French firms to Turkey's entry in the European Customs Union, Temi di discussione (Economic working papers) 715, Bank of Italy, Economic Research Department.

Buono, I., Lalanne, G., 2010. The effect of the Uruguay Round on the intensive and extensive margins of trade, Temi di discussione (Economic working papers) 743, Bank of Italy, Economic Research Department

Caselli, Francesco. 2005. Accounting for Cross-Country Income Differences, Handbook of Economic Growth, in: Philippe Aghion \& Steven Durlauf (ed.), edition 1, volume 1, chapter 9: 679-741

Clerides, S., Lach, S., Tybout, J. R., 1998. Is Learning by Exporting Important? Micro-dynamic Evidence from Colombia, Mexico, and Morocco. The Quarterly Journal of Economics (113), 903-947

Das, S., Roberts, M., Tybout J., 2001. Market Entry Costs, Producer Heterogeneity and Export Dynamics. NBER Working Paper No. 8629 
Debaere, P., Mostashari, S., 2010. Do tariffs matter for the extensive margin of international trade? An empirical analysis. Journal of International Economics 81(2), 163-169

Dixit, A. K., 1989. Entry and Exit Decisions under Uncertainty. Journal of Political Economy (97), 620-638.

Dutt, P. and D. Mitra. 2005. Political ideology and endogenous trade policy, Review of Economics and Statistics 87: 59-72

Eaton, J., Kortum, S., Kramarz, F., 2005. An Anatomy of International Trade:Evidence from French Firms. mimeo.

Epstein David. and Sharyn O.Halloran. 1996. The Partisan Paradox and the US Tariff, 1877-1934. International Organization. 50: 301-24.

Feenstra, R. 1988. Quality Change Under Trade Restraints in Japanese Autos. The Quarterly Journal of Economics, 103 (1): 131-146

Feinberg, Robert. 2005. U.S. Antidumping Enforcement and Macroeconomic Indicators Revisited: Do Petitioners Learn?, Review of World Economics, 141(4): $612-22$.

Feinberg, Robert and Kara Reynolds. 2006. The Spread of Antidumping Regimes and the Role of Retaliation in Filings, Southern Economic Journal, 72(4): 877-90.

Feinberg, Robert and Kara Reynolds. 2007. Tariff Liberalization and Increased Administrative Protection: Is There a Quid Pro Quo?, World Economy, 30(6): 948-61.

Francois, Joseph and Gunnar Niels. 2006. Business Cycles, the Current Account and Administered Protection in Mexico, Review of Development Economics, 10(3): 388-99

Ganguli, B., 2008, The trade effects of Indian Antidumping Actions. Review of International Economics 16(5), 930-941

Grossman, G. E. Helpman. 1994. Protection for sale, American Economic Review 84: 833-850

Hansen, Wendy L. 1990. The International Trade Commission and the Politics of Protectionism, American Political Science Review 84: 21-4

Hansen, J. and J. Nielsen. 2009. Dumping and Injury Margins in Markets with Horizontal as well as Vertical Product Differentiation. Journal of Industry, Competition and Trade, 9(3):233-250 
Hallak, J.-C. and J. Sivadasan. 2008. Productivity, Quality and Exporting Behavior under Minimum Quality Requirements. mimeo.

Hallak, J.-C. 2006. Product Quality and the Direction of Trade. Journal of International Economics 68(1): 238-65

Harrigan J. and H. Deng. 2008. China's local compataive advantage. NBER Working Paper No. 13963

Herguera I., K. Praveen and E. Petrakis. 2000. Quality restrictions and endogenous quality choice. International Journal of Industrial Organization. 18:1259-1277

Heckman, James J. 1979. Sample Selection Bias as a Specification Error, Econometrica 47: 153-161.

Hibbs, D. 1977. Political parties and macroeconomic policy. American Political Science Review 71: 1467-87.

Hibbs, D., D. Rivers, and N. Vasilatos. 1982. The Dynamics of political support for American presidents among occupational and partisan groups. American Journal of Political Science 26: 312-32.

Hirakawa, O., Muendler, M., Rauch J., 2010, Employee spinoffs and other entrants: Stylized facts from Brazil.mimeo

Kennedy, P.E., 1981. Estimation with correctly interpreted dummy variables in semilogarithmic equations. American Economic Review (71), 801.

Kneller and Yu. 2008. Quality Selection, Chinese Exports and Theories of Heterogeneous Firm Trade. Mimeo

Knetter, Michael M. and Thomas J. Prusa. 2003. Macroeconomic Factors and Antidumping Filings, Journal of International Economics, 61(1): 1-18.

Konings, J., Vandenbussche, H., and Springael, L., 2001. Import Diversion under European Antidumping Policy. Journal of Industry, Competition and Trade 1(3), 283-299.

Konings, J., Vandenbussche, H., 2009. Antidumping protection hurts exporters: Firm-level Evidence from France. CEPR Discussion Paper No. DP7330

Konings, J., Vandenbussche, H., 2008. Heterogeneous responses of firms to trade protection. Journal of International Economics, 76(2), 371-383 
Krever, Tor. 2008. The politics of Preferential Trade: Partisanship and the adoption of preferential trade agreements, unpublised manuscript

Krisha, K.. 1987. Tariffs vs. Quotas with endogenous quality. Journal of International Economics, 23:97-122

Kugler, M. and E. Verhoogen. 2008. Prices, Plant Size, and Product Quality. Review of Economic Studies (forthcoming)

Manova, K., 2009, Quality Heterogeneity across Firms and Export Destinations.mimeo.

Melitz, M., 2003. The Impact of Trade on Intra-Industry Reallocations and Aggregate Industry Productivity. Econometrica 71(6), 1695-1725.

Miranda, J. and M. Ruiz. 1998. The International Use of Antidumping: 19871997. Journal of World Trade 32: 5-71.

Milner H. and Judkins B. 2004. Partisanship, Trade Policy, and Globalization: Is There a Left Right Divide on Trade Policy?, International Studies Quarterly 48(1):95-119.

Molina, D., Muendler, M., 2009, Preparing to Export. mimeo

Moore, Michael O. and Maurizio Zanardi. 2008. Trade Liberalization and Antidumping: Is There a Substitution Effect?, ECARES working paper

Nicita A. and M. Olarreaga. 2006. Trade, Production and Protection 19762004, World Bank Economic Review 21(1)

Nielsen, J. U.-M. and A. Rutkowski. 2005. The EU Anti-dumping Policy Towards Russia and China: Product Quality and the Choice of an Analogue Country. The World Economy, 28: 103-136.

Pierce, J., 2009. Plant-Level Responses to Antidumping Duties: Evidence from U.S. Manufacturers. Working Papers 09-38, Center for Economic Studies, U.S. Census Bureau

Pinto, Pablo M. and Santiago M. Pinto. 2008. The Politics of Investment: Partisanship and the Sectoral Allocation of Foreign Direct Investment, Economics \& Politics 20, no. 2: 216-254.

Prusa, Thomas J. 2001. On the spread and impact of Anti-Dumping, Canadian Journal of Economics, 34(3): 591-611.

Prusa, Thomas J. and Susan Skeath. 2002. The Economic and Strategic Motives for Antidumping filings, Weltwirtschaftliches Archiv, 138(3): 398-413. 
Reynolds, Kara M. 2006. Subsidizing Rent Seeking: Antidumping Protection and the Byrd Amendment, Journal of International Economics. 70(2006): 490-502

Rodrik, D. 1995. Political Economy of trade policy. In: Grossman, G.M., Rogoff, K. (Eds) Handbook of International Economics, vol. 3.North Holland, Amsterdam, pp. 1457-1494.

Rogowski, Ronald. 1989. Commerce and Coalitions. Princeton: Princeton University Press.

Romalis, J., 2002. NAFTA's and CUSFTA's Impact on North American Trade. NBER Working Paper No. 11059

Toshimitsu, T. 2005. Tariffs, Quality Choice, and Cost Functions: a Foreign Monopoly Case. Review of International Economics, 13: 376-384

Vandenbussche, H. and X. Wauthy (2001). Inflicting injury through product quality: how European antidumping policy disadvantages European producers. European Journal of Political Economy, 17: 101-116

Verhoogen, E. 2008. Trade, Quality Upgrading and Wage Inequality in the Mexican Manufacturing Sector. Quarterly Journal of Economics 123 (2), p. 489-530

Veugelers, R. and H. Vandenbussche. 1999. European Antidumping Policy and the profitability of national and international collusion. European Economic Review, No. 43/1, pp. 1-28

Zanardi, Maurizio. 2004. Antidumping: What are the Numbers to Discuss at Doha?, The World Economy 27(3): 403-433. 15:1: 165-176 (September) 
VITA

VEYSEL AVSAR

2006

B.A., Economics

Istanbul University, Istanbul Turkey

2008

M.A., Economics

Florida International University, Miami Florida

2010

Doctoral Evidence Acquisition Fellowship

$2010-2011$

Dissertation Year Fellowship

\section{PRESENTATIONS}

Avsar, Veysel (March 2011). Southwestern Society of Economists Annual Conference, Houston, TX, USA

Avsar, Veysel (October 2010). Ryerson University, Toronto, Canada.

Avsar, Veysel (April 2010). 9th Globalization and Economic Policy Postgraduate Conference, University of Nottingham, UK. (Awarded the best paper prize in the conference)

Avsar, Veysel (April 2010). 6th International Students Conference: Empirical Studies in Social Sciences; Izmir University of Economics, Izmir, Turkey.

Avsar, Veysel (February 2010). Eastern Economic Association Annual Conference; Philadelphia, PA, USA

Avsar, Veysel ( June 2008). Deakin and Monash Universities Theoretical and Applied Economics HDR Colloquium, Melbourne, Australia. 